\title{
LÉGI KÖZLEKEDÉS ÉS TERÜLETI FEJLŐDÉS
}

\author{
(Air Transportation and Spatial Development)
}

\section{ERDŐSI FERENC}

Hazánk földrajzi adottságai illetve történelmi fejlódésünk okán valamennyi közlekedési alágazat közül a vasúti, valamint a belvízi közlekedés befolyásolta és differenciálta a legnyilvánvalóbban a területi és településfejlődést. Kevésbé kézzel fogható volt az 1990-es évekig a közúti közlekedés hatása, amely ma is inkább csak az autópályák nagyvárosokhoz közeli szakaszain, többnyire a kistérségi lépték keretein belül maradva nyilvánul meg. Monocentrikus közlekedéshálózati szerkezetünkhöz igazodóan a lényegében egyközpontú magyar légi közlekedés regionális hatásairól egyelőre alig beszélhetünk. Néhány év óta valóságos regionális repülötér építési lázban ég a vidék, de az eufória a valós lehetőségek tükrében csak néhány esetben megalapozott. A hazai tértudományok müvelőinek - érthető módon - kevés megbízható információjuk van a légi közlekedés és a település/terủletfejlesztés kölcsönhatásáról. Cikkünk közreadásával szeretnénk szerény mértékben hozzájárulni a vonatkozó ismeretek gyarapításához.

\section{Általános összefüggések}

A többi közlekedési alágazathoz hasonlóan a légi közlekedés és a gazdaság kölcsönhatásban van egymással. Altalános érvénnyel igaz, hogy mennél fejlettebb a légi közlekedés, annál nagyobb mértékben jảrulhat hozzá a gazdasági fejlödéshez, és mennél magasabb szinten áll egy ország gazdasági-társadalmi szempontból, annál színvonalasabb a légi közlekedése. E megállapítások alól azonban ismeretesek kivételek, ezért a kölcsönhatások csak bizonyos kiegészítésekkel, illetve a gazdaságnak csak bizonyos szektoraira érvényesek.

- Vannak olyan sûrûn lakott, kiváló földi közlekedési hálózatnak örvendö kis területü, igen fejlett országok, amelyeknek alig van belföldi légi közlekedése. Ezen országokban tehát csak a külkapcsolatok, a külgazdaság szempontjából lehet pozitív hatása a (nemzetközi) légi közlekedésnek (Hollandia, Belgium, Svájc, Luxemburg stb.). Ezekben az országokban eleve nem lehet igazi regionális gazdaságfejlesztô tényező a légi közlekedés a nemzetközi repülötér (Brüsszel) vagy repülőterek (Zürich, Genf) térségének kivételével.

- Differenciálja a légi kőzlekedés által előálló nemzeti jövedelmet az a körülmény is, hogy van (vannak)-e egy orszägnak saját légivállalata(i), amely(-ek) képes(-ek) a légi szolgáltatások irấnti kereslet túlnyomó részét kielégiteni, jövedelmének (akár adózás formájában is) legnagyobb részével az anyaország nemzeti jövedelmét gyarapítani. Ha egy ország légi közlekedési igényét elsősorban idegen 
társaságok látják el, a kơzvetlen gazdasági haszon (az ugyancsak múkődő adózás, a sokféle illeték ellenére) jóval kevesebb.

- A politikai rendszerek értékrendjében eléggé eltérő lehet a légi közlekedés fontossága, ami azután egyes országok kőzlekedés-politikájában is tetten érhetö. A diktatórikus berendezésủ, tervgazdaságra berendezett országok és a demokratikus piacgazdasági országok eléggé eltérö légi közlekedésfejlesztési politikát folytatnak. A diktatúrák előszeretettel építenek ki és tartanak fenn igen erős állami szubvencióval olyan belfoldi hálózatot - elsősorban a centralizált államigazgatás, implicite a fegyveres testuletek érdekében -, amely folyamatosan veszteséget termel, de propaganda célokra használható, mikőzben az elzárkózás, az idegen országokkal szembeni konfrontálódás miatt a nemzetközi légi forgalmat csak a legszükségesebbre (általában a hivatalos ügyben külföldre utazók kőzlekedésére) korlátozzák.

- A politikai-gazdasági rendszerektöl függ az is, hogy milyen mértékben érvényesül a repülöterek közvetett gazdasági-regionális hatása. Ahol a piaci folyamatok nem érvényesulhetnek, ahol nincs szabad mozgás, ahol nem kész a társadalom az innovációk fogadására, ott a repülőterek alig váltanak ki áttételekkel területfejlesztési folyamatokat.

A légi kőzlekedés a legegyértelmübben és a leglátványosabban azokban az országokban bizonyítja nagy szerepét a nemzetgazdaságban, ahol az igen alacsony népsürüség, a nehezen leküzdhető természeti akadályok, a földi kőzlekedési hálózat elégtelensége miatt tulajdonképpen az egyetlen teljesitőképes közlekedési eszkőz szerepét tölti be, majdnem monopolhelyzetben van. A rászorultság miatt nélkülözhetetlen, ezért még a legszegényebb, legelmaradottabb afrikai, latin-amerikai, ázsiai országokban is létrehozzák anyagi erejüket meghaladó méretekben. (Áruszállitáshoz, éhezőknek nyújtott élelmiszersegélyek eljuttatásához, az államapparátus müködtetéséhez.)

A fejlett demokratikus országokban normálisan müködỏ légi kőzlekedési rendszer egyaránt segiti a kül-és belkereskedelem funkcionálását, mint ahogy a munkavállalók szabad mozgását, mobilitását is elōmozdítja. A légi kơzlekedés lehetỏvé teszi a javakkal való ellátás magasabb szintjét, és elösegíti a lakosság (ismeretek gyarapitásával is járó) élvezetesebb szabadidó eltơltését, a kulönféle nemzetiségü emberek egymáshoz közelebb kerülését. A kőltségek csökkentése és a verseny szempontjából a teljesitóképes közlekedési rendszer elengedhetetlen feltétele a terulleti munkamegosztás elönyét egyre jobban kihasználó nemzetgazdaságok múkỏdésének.

Pontos számitásokat eddig még nem végeztek arról, hogy a légi kőzlekedés hatása milyen mértékủ a gazdasági élet fejlödésére. Az azonban vitathatatlan, hogy a foglalkoztatottak számarányához, de még az állóeszköz-állományához képest is jóval nagyobb mértékben járul hozzá a GDP, illetve a nemzeti jövedelem termeléséhez, azaz népgazdasági szempontból a leghatékonyabb értéktermelö tevékenységek közé tartozik, amelynek egyre nagyobb a szerepe a nemzetközi munkamegosztás gyors kibontakozásában, hatékonyságának javulásában. 
Tér és Társadalom, 13. 1999. 4. 45-76. p.

A nemzetkőzi légi közlekedésnél maradva először a közvetlen gazdasági-foglalkoztatási szerepét kell tisztázni, amely a részarányszámok tukkében mindenhol csekélynek tünik.

Így pl. az USA-ban - a gyorsütemü fejlödés ellenére - az 1960-as években a nemzetközi légi közlekedésböl a bruttó jövedelemnek csupán a 0,05\%-a származott, és a repülés a dolgozóknak mindössze a 0,03\%-át foglalkoztatta. 1993-ban ezek a részarányok mindössze 0,08\%-ra, illetve 0,04\%-ra módosultak. Hollandiában ugyan a KLM az ötödik legnagyobb munkaadó, azonban csak a foglalkoztatottak $0,35 \%$-át mondhatja magáénak. Svájcban a Swissair részesedése a bruttó nemzeti jövedelemnek csak az 1,2\%-át teszi ki.

Ha a nemzetközi légi közlekedésnek a nemzeti fizetési mérlegre való hatását nézzük, e tekintetben is csak szerény részarányokkal találkozunk. Az USA-ban a légi közlekedésböl származó bevétel az egész belkereskedelemi forgalom összegének alig $2 \%$-át adja.

A légi közlekedés közvetlen hasznánál, a belőle származó pénzjővedelemnél jóval nagyobb az áttételes, közvetett haszna a gazdaságra nézve. (Ezt az angol szakzsargon a „social overhead capital" kategóriába sorolja.) Ez annyit jelent, hogy a légi közlekedés egy olyan elengedhetetlen feltétel, amely lehetővé tesz és elömozdít más gazdasági tevékenységeket. A légitársaságok ugyan elöszeretettel nevezik magukat „iparnak”, azonban tény, hogy a légi közlekedés egy fajta kőzlekedési szolgáltatás, ilyen minőségben van rá szuikség a mai világgazdaságban. A légi közlekedés elösegíti, hatékonnyá és így gyưmölcsözővé teszi a kereskedelmet és a turizmust, megkönnyiti új piacok feltárását a saját országhatárain kívull, és meggyorsítja az emberek, eszmék és javak cseréjét. Természetesen ezek a közvetett hasznok számszerũen sokkal nehezebben mutathatók ki.

Pl. meg lehetne kísérelni kideríteni, hogy a svájci, osztrák vagy holland utasok külföldön és a külföldi utasok Svájcban, Ausztriában, Hollandiában mennyi pénzt költenek el, vagy hogy a svájci, osztrák, holland uzletemberek légi utazásaik során mennyi frank, schilling, gulden értékben szereznek külfoöldön megbízást országaik számára, és mennyi megrendeléssel térnek haza. Ezeknek az összegeknek a számbavétele kiindulási pontot adhat annak a kimutatására, hogy a légi közlekedés valóban mit hoz egy olyan országnak, mint pl. Svájc. Ez azonban csak egy elméleti kiindulási pont: egyrészt nyilvánvaló az ilyen adatok beszerzésének nehézsége, azután azt is bizonyítani kellene, hogy a kimutatott utazások és ủzletkötések repülỏgép nélkul egyáltalán nem vagy csupán nagyon kis mértékben jöttek volna létre. (Nyilvánvaló, hogy egy résziuket repülőgép nélkül is realizálni lehet.)

Ha egzakt számitásokon alapuló, pontos adatokkal nem is, de a tapasztalatok alapján bizonyitható a légi közlekedés fontossága, hiszen egy olyan tengerpart nélküli országban, amelynek nagy a nemzeti jövedelme és igen erösen a külkereskedelemre orientált, amelynek külgazdasági kapcsolatai szinte az egész világra kiterjednek, nyilvánvalóan egészen eminens a nemzetkőzi légi közlekedés szerepe.

Ezt támasztják alá a vállalati adatok is. Pl. már 1964-ben egy svájci multinacionális nagyvállalat az alkalmazottai részére napi átlagban 15 repülöjegyet vásárolt a legkülönbözőbb küllföldi célvárosokba repulléshez, 1993-ban pedig 28-at. Ez érzékletesen jelzi, hogy milyen nagy feladatot teljesit a légi közlekedés a szolgáltatásaival az ország külgazdaságában. Azonban más szektorokban is tetten érhető a légi közlekedés intenzív használata. Így pl. a bankok szinte nélkülözhetetlennek tartják a sikeres, megbizható üzlethez a személyes megbeszélést, az ügyféllel való megismerkedést, a megbizhatóságáról való információgyủjtést és 
impresszió-szerzést a távoli országban. Nem kủlönben az adott ország gazdasági-politikai viszonyainak - helyzetének, folyamatainak - helyben tanulmányozása adhat megbízhatóbb adatokat a bankkölcsönökkel, befektetésekkel kapcsolatos döntésekhez.

A személy - és áruszállítás gyorsításával a légi kőzlekedés is hozzájárult a második világháború óta végbement gyors gazdasági fejlödéshez, életszínvonal növekedéshez. Fejlődés ugyan légi kőzlekedés nélkül is végbement volna, de az integrációnak, a globalizáltságnak az a mértéke, ami a modern világgazdaságot jellemzi, aligha jőtt volna létre légi kơzlekedés nélkủl. A nemzetkơzi, világot átfogó légi kởzlekedéssel kialakult szövevényes nemzetközi gazdasági kapcsolatok ugyanis az egész világon megmutatkoznak. Másfelöl a légi közlekedés hatásmechanizmusa tompítja bizonyos mértékig a gazdasági fejlődés ciklikusságát.

Amíg az 1960-as években a légi közlekedést igénybe vevők kőzött nagyjából egyforma arányt képviseltek az üzletemberek és a turisták, a jóléti társadalom kibontakozásával számos országban a turizmus ma már messze megelözi részesedési sủlyában az üzleti célú repülést. $\mathbf{A}$ modern telekommunikáció ugyanis az ủzletemberek számára jó néhảny esetben lehetơvé teszi a személyes megjelenés nélküli ügyintézést, viszont a turisztika lényege a látnivalók, a természeti és kulturális stb. értékek helybeni élvezete, hiszen a televiziózás a személyes élményt nem helyettesítheti. Ismét csak az Alpok államaira vonatkoztatva: a külfóldi (nem kis részben repülőgéppel érkezó) turisták által Svájcban, Ausztriában, az olaszországi Alpokban elköltơtt összeg lényegesen nagyobb az alpesi térségböl származó turisták által kưlfóldön kőltớtt összegnél.

Végső soron jó néhány ország, tartomảny (Kanári-szigetek, Seychelle-szigetek, Mauritius, Baleárok, Maldív-szigetek, Sri Lanka, Ciprus stb.) tulajdonképpen az ùdülók tömegeit szállítani képes modern légi közlekedésnek köszönheti idegenforgalmi potenciálja hasznositásának lehetőségét, ezáltal gyors amyagi gazdagodását (amivel persze szembeállíthatók a környezetpusztulás gondjai, a bủnözés, a bennszülött lakosság mentalitását károsan befolyásoló életmód változás, életfelfogás torzulás), mivel a vendégek száma, ha tengeri úton érkeznének a távoli Európából és Észak-Amerikából, csupán a tôredéke (ötß̋de-nyolcada) lenne a jelenleginek.

\section{A légi közlekedés és a földi tớvolsági közlekedés (A nagysebességü vasutakkal folytatott verseny)}

A légi közlekedésnek csak akkor támadhat igazi versenytársa a földi közlekedésfajták körében, ha azok hasonló, vagy legalábbis kőzelító minőséget tudnak nyújtani a személy- és teherszállítási szolgáltatások terén sebességben, árban, menetrendszerüségben, megbizhatóságban.

A kőzúti kőzlekedés mintegy 600-1000 km-es távolságra ár tekintetében lényegesen kedvezỏbb az utas szempontjából, ha eltekint a vezetés făradalmától, ha nem tényezó az eljutási idő. Ennél nagyobb távolságokra viszont - civilizált életmódot feltételezve - csak a költségeket nőveló éjszakai szállás igénybevételével lehet eljutni, igy minél tỏbb éjszakát illetve napot vesz igénybe az út, annál jobban közelítenek az összes ráfordítások (a többszöri étkezéssel is számolva) a légi út költségéhez. Sebességben nincs esélye a közúti közlekedésnek arra, hogy felvehesse a versenyt a repuilőgéppel, mivel az autópályák engedélyezett legnagyobb sebessége $110-130 \mathrm{~km} /$ óra. 
Ellenben az 1960-as évektől Japánban, majd Franciaországban, Németországban, Olaszországban és Svédországban több pályán max. 280-300 (de általában 200-220) $\mathrm{km} /$ óra sebességgel közlekedtetett szuperexpressz vonatok a rövidebb $(400-600 \mathrm{~km}$ es), szárazfôldek feletti légi járatoknak megfeleló szervezés (pl. repülötértöl repülőtérig nyújtott szolgáltatás) mellett esélyes versenytársai lehetnek. A légitársaságok azonban még nem reagáltak megfelelõ mértékben a nagysebességú vasutak általi kihivásra.

A német légi közlekedésben közvetlenül részt vevő vállalatok (tehát a légi közlekedési társaságok és a repưlöterek) a Német Szövetségi Vasutak lendületes fejlesztési erőfeszítéseit eléggé figyelmen kívull hagyták.

Ebbéli érdekük nagyon különbőző:

A német Lufthansánál a belföldi viszonylatú forgalom az utasszámban mért összforgalmának ugyan az 1/3-át teszi ki (utasszámban), azonban a rövid úttávolságok miatt a Lufthansa által értékesített összes utaskilométer mennyiségnek mindössze a tizede jutott a belföldi forgalomra. A nagy légitársaság (mint „forgalomhordozó”) érdekeltsége a rövid tóvú közlekedésben tehát csak mérsékelt; fökẻnt a közép-és hosszú tơvú közlekedés a kifizetödöbb számá$r a$, ezért nem is nagyon bánta volna, ha nem kellett volna rơvidebb vonalakkal bajlódnia.

Egészen mások a német közhasználatú repülöterek érdekei a rövid távú légi közlekedésben. A Lufthansával ellentétben az értékesített utaskilométerek nem határozzák meg a gazdasági sikert. A repülöterek számára egyedül a repülöterek fö bevételeí, a felszállási és leszállási illeték, kezelési illetékek, a boltok és éttermek forgalma a fontosak. Ȧz utasok fele, kétharmada repülőterektől fúggỏen max. $600 \mathrm{~km}$ hosszú légiutakat vesz igénybe.

Ezért a repülöterek tulajdonosai illetve üzemeltetői számára létkérdés a repülótéren megforduló utasok számának megtartása, ehhez kemény anyagi érdekeik füzödnek.

Annak érdekében, hogy a belföldi légi közlekedést az utasok számára vonzóbbá tegyék a rövid tóvolságra utazók (,aktatáskás utasok”) gyors kezelésére néhol már különleges, egyszerüsített, csupán tíz percet igénybe vevơ kezelési rendszert hoztak létre, továbbá a repülőgép földön tartózkodási idejét (amely jelentős részét teheti ki az egész kőzlekedési időnek) felével, harmadával csökkentették.

A repülöterek ésszerüsitett utaskezeléssel csökkentették a légi közlekedéshez szükséges idót, nem kell tehát a menetsebességet nővelni, ami nagy kỏltségnővekedéssel járna. A nagysebességủ vasutak viszont csak a sebességük további növelésével képesek nagyobb vonzeröt gyakorolni az utasokra. A rövid távolságú légi közlekedésbeli technikai újitások és az ésszerübben elosztott illetékek is javithatjảk a légi közlekedés esélyeit. A jelenlegi illetékarányok ennek erösen ellene dolgoznak.

A repülőtéri illetékek (leszállási illetve kezelési illetékek) százalékos költségaránya a légi járat összköltségeihez viszonyítva számszerủen nagyjából a következők: hosszú utakon $4 \%$, közép távolságú utakon $8 \%$, rövid távolságon $17 \%$.

A rövid utakon tehát az utas számára is a legkedvezötlenebbek a repüloótéri illeték arányok, azaz a rövid tơvú repülés érzékenyebb a reptéri illetékre. A nagysebességú vasúttal való versenyben ellentétes irányú mozgás alakul ki az árak és a forgalom nagysága között. A nagyobb arányú repülőtéri illetékkel is elöállított magasabb repülöjegy-árak következménye az utasok egy részének vasútra átterelödése lehet. (Kereskedelmi szempontból a repülőterek számára ez az összefüggés alapvetően fontos, mivel nem az illetékek nagysága, hanem a forgalomtól fủggő szolgáltatásaik 
eredményezik a bevételeket.) A repülóterek illetékrendszerének ủjrafelosztásóval lehetôvé válhat az egyelöre a rövid távolságú repülést nagyon hảtrảnyosan befolyásoló, magas összegek csökkentése, és ezzel a nagysebességü vasutakkal szembeni versenyhelyzet erôsödhet.

Egyelöre Európában, de tulajdonképpen Japánban is a vasút és a légi közlekedés közötti verseny a két közlekedési ág hálózatának csak kisebb, de fontos részterületein, néhány szakaszán játszódik le. Mindent egybevetve, a két közhasználatú közlekedési eszköz tevékenységének súlypontjai messze fekszenek egymástól. Sokkal több az olyan helyzet, ahol a kooperáció és nem a verseny a kérdéses. A vasút és a légi közlekedés együttesen védekezhet a közúti közlekedés lehengerló versenye ellen. A nagysebességü vonatok közlekedtetése a vasútnak új piaci lehetỏséget nyit, ami a légi kőzlekedést is új kezdeményezésekre ösztönözheti.

\section{A repülőterek mint a területi fejlődés mind rangosabbá váló tényezõi}

A légi közlekedés területfejlesztési hatásainak jellemzői alapvetően különböznek a földi közlekedéstöl, mivel a közúti közlekedéshez, de még a vasúti közlekedéshez képest is jóval ritkább hálózatot képez. Ennek megfelelöen az igénybevételét lehetővé tevö primer szállitási pontjainak (repülötereknek) a száma is sokkal kevesebb, mint a vasútnak (állomások, megállóhelyek), nem is beszélve a közúti közlekedés szinte végtelen számú induló- és érkezô pontjáról.

Ennek megfelelön a fơldi közlekedés hatásai a területek sủrü behálózásával, feltárásával felületszerúek (kétdimenziósak), viszont a légi közlekedésé inkább pontszerü (a „pontgazdaság”"-gal asszociál); bár a repülőterekröl (mint a hatóeró „támadási pontjairól”) kiinduló, „kisugárzó" hatások bizonyos mértékig ugyancsak felületszerủek.

A repülöterek gazdasági (és nemegyszer gazdaságon kívüli, tágabb értelemben vett kulturális, társadalmi) hatásai sokfélék; mind a hatótényezök, mind a terưleti lépték, mind a repülöterek adottságai és a hatások jellege, természete, megnyilvánulási formája jó néhány változatban jelennek meg a repülöterek és a területi fejlödés kölcsönhatás-rendszerében. Ugyan a repülöterek által kiváltott területi gazdasági hatásokat mutatjuk be, nem szabad megfeledkeznünk arról, hogy az adott terület (elsösorban mint gazdasági környezet) tulajdonságai sem kőzömbösek egy repülötér fejlödésének mérete és jellege szempontjából.

A repülöterek területi-gazdasági hatásainak vizsgálatára több szempont is kínálkozik, igy például:

- A szektorok, ágazatok szerinti hatások (pl. iparra, szolgáltatásokra, esetleg mezögazdaságra nézve milyen következményei vannak),

- milyen léptékben, mekkora vonzásterületen nyilvánulnak meg a területi hatásai (pl. helyi, regionális, régión túli, nemzetközi téren),

- makrogazdasági és vállalati szintü hatások (a vállalatin belül a repülöteret mükơdtető vállalatnál mutatkozó, az általa generált hatások és a vonzáskőrzeti, vagy azon túli vállalatok tevékenységében - telephely választásában, profilválasztásában - illetve módosításában tetten érhetö hatások.) 


\section{A repülôtér mint vállalat, illetve mint gazdasági tényezỏ}

A közhasználatú repülőterek gazdasági státuszuk szerint tulajdonképpen olyan objektumok, amelyek rendelkeznek a más szektorbeli közép- és nagyvállalatok valamennyi alapvetó jellemzőjével, beleértve a létrehozásukkal és üzemeltetésưkkel kapcsolatos helyi fejlesztőerő megnyilvánulását is.

A repülôtér-vállalatok gazdasági jelentőségét az általuk keltett beruházás és fogyasztás nagysága határozza meg.

A repülötéri beruházásokból fỏként négy gazdasági alágazat részesedik:

- a magasépítés,

- a mélyépítés,

- a közlekedési eszköz- és készülék-gyártás,

- az irodai és központi létesítményi berendezéseket gyártó iparágak.

A repülőtéri beruházások hatása részben áttételesen érvényesül, részben pedig közvetlenül (utóbbiak a repterek építésénél kifizetett bérekkel, szolgáltatásokkal).

A repulőterek létesítése, karbantartása, időnkénti fejlesztése komoly keresletet támaszt a beruházási javak (építőanyagok, nagy értékü, gyakran a csúcstechnika körébe tartozó gépek, berendezések, müszerek stb.) iránt, amelyek csak részben szerezhetök be a környéken, nem egyszer importból származnak. Az üzemeltetéshez szükséges áruféleségek (catering, boltok, közmüvek számára) is nagyon különböző távolságban szóródó beszerzési forrásokból származnak, de közös vonásuk, hogy erősítik a kereskedelmet, és áttételesen növelik a foglalkoztatást az árukat elöállító helyeken. A repülöterek által fizetett helyi és állami adók is jelentős tényezök, bár ezekkel mindig szembe kell állítani a létesítésükhöz eszközölt állami és önkormányzati hozzájárulásokat.

Általában gazdaságilag fontosabbak a közvetlen foglalkoztatási hatások, miutån a repülöterek jóval nagyobb foglalkoztatási központokká váltak, mint akár a nagy pályaudvarok, vagy egyéb földi közlekedési csomópont komplexumok. Ez annak a következménye, hogy nem csak nagyszámú, de többnyire az igényesebb társadalmi rétegekhez tartozó utasnak nyújtanak sokféle (személyi) szolgáltatást, amelyek gépesítésének, automatizálhatóságának a lehetőségei igencsak korlátoltak. Így a repülötérgazdaság a „legmunkaerőintenzívebb”, azaz sok személyt foglalkoztató, sok élőmunkát igénylő gazdasági ágazatok közé tartozik.

\section{A repülöterek mint minőségi foglalkoztatási központok}

A világ legnagyobb repülöterei nemcsak a közlekedési-müszaki infrastruktúra kiemelkedö koncentrációi, hanem különleges méretü foglalkoztatóhelyek is, amelyek rendszerint helyet adnak légitársaságok adminisztratív központjainak, vagy legalább is jelentős részlegeinek, kirendeltségeinek. A megarepülötereken és a hozzájuk tartozó repülögépeken fedélzeti személyzetként majdnem annyi az alkalmazott, mint amennyi vasutas dolgozik Magyarországon. Még a „második lépcsőt” alkotó nagy európai hub repuilőtereken is több tízezer ember keresi a kenyerét. A 
repülöterek, illetve az oda települt légitársaságok az átlagosnál jóval képzettebb, sỏt nagy arányban kifejezetten magasan kvalifikált munkaeröt foglalkoztatnak, nagy gondot fordítanak a továbbképzésre, alkalmazottaik egészségére, és minden szempontból igényessé nevelik az alkalmazottakat. Túlzás nélkưl állítható, hogy a repülöterek (mind a müszaki kultúra, mind a képzés, a más munkaterületekre is konvertálható tudás alapján) egyfajta innovációs központi szerepet is betöltenek.

$A$ repülöterek a legmunkaigényesebb munkahelyek közé tartoznak, sok élömunkát igényel az ellátásuk.

Példa erre a frankfurti „Majna-Rajna Légikikötö”, ahol az alkalmazottak, a bevételek, a közlekedő repứlógépek és utasok száma (mint a közlekedési teljesítmény indikátorai) között lényeges összefưggések állapíthatók meg. A növekvö automatizálás ellenére a foglalkoztatottak számának ingadozása erósen az utasok számától függó módon ment végbe. Ezt az összefüggést a statisztikai regresszióanalízis egyértelmüvé teszi. A korrelációs koefficiens 0,991-es értéke kifejezetten erős ősszefüggésre utal. A meghatározottság koefficiens igen magas, 0,982-es értéke is összecseng ezzel.

Németország nyugati részén a 12 legnagyobb repülőteret üzemeltető társaság alkalmazottainak létszáma 1990-ben már 22 ezer fỏ volt. A repülóterekre telepult hatóságok, a különbözó légitársaságok, valamint a légi közlekedési szektorok egyéb cégeinek kirendeltségein, irodáiban és uzemeiben tevékenykedőkkel együtt az összes foglalkoztatottak száma 113 ezer fót tett ki.

Az utóbbiak közé tartoznak az igazgatásban, a fỏldi szolgálatokban múködők és a repülöszemélyzet mellett a légi teherszállítmányozók, expressz szolgáltatást végzỏk, utazási irodák és engedélykiadók, valamint az ưzemanyag és fütỏanyag szállítók, továbbá az utasellátó cateringcégek munkahelyei. Egyedül a fedélzeti ellátásért felelös Lufthansa Service GmbH 10 izemet tartott fenn 1989-ben, 5,6 ezer foglalkoztatottal.

Ebböl világosan kitünik, hogy a repưlötér mint vállalat közvetlen hatásai és a repưlötér mint kőzlekedési szolgáltatásokat nyújtó létesítmény közvetett hatásai nem mindig határolhatók el élesen egymástól. Mindkét hatás megmutatkozik az üzemek telephelyi kötődésében.

Egyes tơredékes információk alapján megállapítható, hogy az 1990-es évek derekán az ósszes foglalkoztatottak száma az egy évtizeddel korábbinak az 1,2-2 szerese. (E téren alapvetỏen új helyzet állt elő Münchenben, ahol az új repülötér a korábbihoz képest kétszerannyi embernek ad munkát.)

A tơbb tízezernyi (vagy a közepes repterek esetében akár csak több száznyi, ezernyi, az átlagosnál jobban fizetett és nagyobb vásárlóerejủ alkalmazott nemcsak az általuk eltartott családtagjaik, hanem a számukra kưlönféle szolgáltatásokat nyújtók révén közvetve is növeli a repulötérből élők széles táborát. Ennell is nagyobb tömeget tesznek ki azok, akik a repullőterek, az utasok számára végzett munkából élnek. Ide tartoznak a repülötérre közlekedó jármüveken szolgálók (beleértve a taxisofóröket is), a repưlöterek épitő-szerelö és egyéb munkáira megbízott külsỏ vállalatok emberei, közöttuk a repülötéri üzletek, valamint az utasok fedélzeti ellátásához árukat szállító cégek alkalmazottai stb.

Európa több repưlőterén vizsgálták, hogy a repülötéren közvetlenül alkalmazottakhoz képest milyen hányaddal nagyobb az áttételesen foglalkoztatottakat is magában foglaló összes foglalkoztatottak száma. E multiplikátor szorzót Zưrìchben 
1,6-szorosnak, Frankfurtban 1,63-szorosnak, az NSZK repülőterei átlagában pedig 1,93-szorosnak találták. Ez gyakorlatilag azt jelenti, hogy a repülỏtereken foglalkoztatott minden egyes személy további másfél munkahelyet teremt. A kölcsönhatás természetesen a „visszatérö ágában” is érvényes, azaz ha a repülőtéren megszünik egy munkahely, akkor bỏ másféllel kevesebb lesz a repülötéren kívüliek száma. A brit repülöterek foglalkoztatásáról és a forgalomhoz viszonyított arányáról az l. táblázat tartalmaz - egymástól erősen különbözỏ - adatokat.

\section{TÁBLÁZAT}

Brit repülôtereken foglalkoztatottak száma és a fajlagos foglalkoztatós szintje (Number of Employed Persons by British Airports and Specific Employment Level)

\begin{tabular}{|l|c|c|c|c|}
\hline \multicolumn{1}{|c|}{ Repülőtér } & Év & $\begin{array}{c}\text { Utasok száma } \\
(1000)\end{array}$ & $\begin{array}{c}\text { Közvetlenul } \\
\text { foglalkozta- } \\
\text { tottak száma }\end{array}$ & $\begin{array}{c}\text { Repülötéren } \\
\text { foglalkoztatott/ } \\
1000 \text { utas }\end{array}$ \\
\hline $\begin{array}{l}\text { London-Stansted terv } \\
\text { (minimum) }\end{array}$ & 1998 & 15000 & 16125 & 1,08 \\
\hline $\begin{array}{l}\text { London-Stansted terv } \\
\text { (maximum) }\end{array}$ & 1998 & 15000 & 22865 & 1,52 \\
\hline Leeds/Bradford & 1986 & 511 & 663 & 1,30 \\
& 1990 & 834 & 910 & 1,09 \\
\hline East Midlands & 1986 & 1122 & 2070 & 1,84 \\
\hline Birmingham & 1990 & 1289 & 3950 & 3,06 \\
\hline Manchester & 1989 & 3333 & 3806 & 1,14 \\
\hline London-Gatwick & $1985 / 86$ & 15211 & 15447 & 1,26 \\
\hline London-Heathrow & $1985 / 86$ & 31300 & 46860 & 1,02 \\
\hline Newcastle & 1990 & 1544 & 1500 & 0,98 \\
\hline
\end{tabular}

Forrás: Légitársaságok adatközlése.

A regionális repülőterek elvileg ugyancsak előidéznek közvetlen és közvetett hatásokat, ezek azonban a kis forgalom folytán meglehetösen jelentéktelenek. (A repülőteret üzemeltető vállalat általában nem foglalkoztat 100-300 fönél többet, de a többi jelenlevő vállalat valamennyi repülótéri alkalmazottját beszámítva sem haladja meg az összes foglalkoztatottak száma a 250-600 föt.) A regionális repülöterek jelentösége tehát nem annyira a foglalkoztatási és bevételi hatásokban, hanem sokkal inkább a telephely funkciójában nyilvánul meg.

A következőkben röviden bemutatjuk néhány nagy európai nemzetközi repülötér, illetve kapacitás-fejlesztésük foglalkoztatási hatását.

Amszterdam repülőtere alkalmazottainak száma 34700 fó volt 1990-ben, 2015-re 57300 fönyi állománnyal számolnak. Azonban a repülötér által kőzvetetten indukált foglalkoztatás körébe tartozók száma 1993-ban már elérte a 75 ezret, és 2010 -re 125 ezerre becsülik a repülobtér által közvetlenül foglalkoztatottak és azok együttes számát, akik a repülötér áttételes térségi fejlesztő hatásának köszönhetik állásukat. (Igaz, az utóbbi elöre jelzett adat tartalmazza azokat is, akik majd a tervezett új, ötödik kifutópályát építik.) Hollandia legnagyobb 
repülőtere egymaga termeli meg az ország nemzeti termékének $2,8 \%$-át! A repülötérrel kapcsolatos 50 ezer fós foglalkoztatási nővekmény az egész régió várható foglalkoztatási növekményének a 35\%-át teszi ki (2. táblázat).

Manchesterben a 2. számú kífutópálya építésének megkezdése elött 16,6 ezer fó dolgozott a repülőtéren, az indirekt hatások révén pedig 1993-ban osszesen 45,8 ezer munkahely volt a repủlőtértől fưggő. Amennyiben nem valósul meg a 2. sz. kifutópálya, úgy a repülőtér 2005ben még így is 77,8 ezer munkahelyet tart fenn, ha megépull az új pálya, úgy 96,4 ezret. Manchester csupán a transzatlanti járatok számának nơvelésétől 2000 új munkahelyet vár.

Magának Zürich repülőterének ugyan „,ssak” 21 ezer alkalmazottja van, de külơnféle „,kisugárzásaival" összesen 44,9 ezer embernek biztosít munkát, azaz Svajc gazdaságilag legerősebb agglomerációja foglalkoztatottjainak $8 \%$-a köszönheti valamilyen formában munkáját a repülőtérnek, amely 5,4\%-kal járul hozzá az egész Zürichi kanton bruttó termelési értékéhez.

London Heathrow-n, ha megépítik az új, 5. sz. terminált, azzal a kőzvetlenül foglalkoztatottak száma 53800 föről 78100 fơre, a közvetlenül és kőzvetetten foglalkoztatottaké együttesen 125 800-ról 180000 fơre növekszik. Ez a növekmény 3 billió angol font (4,5 billió dollár) jơvedelem tơbbletet hozhat.

Az előbbi „világrepulőtérhez” képest jóval kisebb a lyoni Satolas repülötér, amelynek 2500 alkalmazottja évi 4 millió fös utasforgalmat tesz lehetóvé.

\section{TÁBLÁZAT}

Amszterdam-Schiphol repülötér tervezett ötödik kifutópályája épitésének foglakoztatási vonzata (Effect on Employment of the Construction of Planned, Fifth Runway in Amsterdam-Schiphol Airport)

\begin{tabular}{|c|c|c|}
\hline Foglalkoztatási kategória & 1990-ben fó & 2010-ben fo \\
\hline Közvetlenủl (a repülőtéren) foglalkoztatottak & & \\
\hline Utasokkal foglalkozók, szolgáltatók & 8800 & 14300 \\
\hline Áruszállitással foglalkozók & 3600 & 8700 \\
\hline Repulőgépekkel, szervizelésükkel foglalkozók & 9000 & 12300 \\
\hline Egyéb foglalkoztatottak (irányítókkal egyưtt) & 13300 & 22000 \\
\hline Összesen & 34700 & 57300 \\
\hline $\begin{array}{l}\text { A közvetett ill. áttételes módon foglalkoztatottak } \\
\text { összesen }\end{array}$ & $75000^{*}$ & 125000 \\
\hline
\end{tabular}

*1993. evi adat

Forrás: Légitársaságok adatközlése.

\section{A repülötér mint gazdasági tényezõ}

A legnagyobb nemzetközi megarepülóterek a saját és az oda települt vállalatok száma, azok pénzforgalma, állóeszköz értéke alapján is világvállalati nagyságrendúek, elérik a multinacionális vállalatok mértékét, de még az országos jelentőségüek is nagyvállalati léptéküek. (A frankfurti repülötér árbevétele mintegy 2 milliárd, a düsserdorfié 550 millió DM évente.)

Kapacitásaik alapján a repülôterek bruttó értéktermelése éppen ügy, mint foglalkoztatottjaik száma, más gazdasági ágazatokhoz képest, erổsen növekszik. (Pl. miközben az egész közlekedés részaránya az NSZK teljes értéktermeléséből 1960 óta csökken, a repülőtér gazdaság és légi közlekedési társaságok értéktermelése jelentösen növekedett - igaz, nagyon alacsony szintröl indultak.) 
A repülőterek létezése, üzemeltetése által keletkezett adókat mint alanyi és önkormányzati bevételeket differenciáltan kell megítélni, mivel a repülötársaságok a nagyszabású és rendkívưli tőkeigényes új repülőtér épitések és bővítések idején nagyösszegú állami támogatásokat vesznek igénybe, amelyek rövid távon nem hoznak jövedelmet.

\section{Fejlesztő hatásuk a környezetre}

A repülőtéri illetékekből, kưlönféle bérleti dijjakból, a földi közlekedési szolgáltatások ellenértékeiböl, a kisegító és melléküzemek, valamint egyéb ellátó szolgáltatások dijaiból a légitársaságokhoz befolyó bevételek, amennyiben azokat új építmények, fejlesztések beruházásaira és fenntartására forditják, a környékükön növekedési folyamatot inditanak el.

Különleges jelentösége van a repülötéri beruházásoknak mind a közvetlen foglalkoztatási és bevételi hatások, mind az indirekt multiplikátor-hatások keltésében. Egy vizsgálat szerint az 1982-1986 közötti repülötéri beruházások Németországban 83\%ban az épitöipar, 11\%-ban a közüti jármü-és gépipar, 6\%-ban az irodagép-, elektrotechnikai, finommechanikai és optikai ipar között oszlottak meg. Mivel a beruházásokban döntöen részt vevö épitöipari vállalatok rendszerint helybeliek vagy legalábbis régióbeliek, a beruházásokból elsősorban a helyi-regionális gazdaság profitál, tehát a repülōtér által kiváltott másodlagos hatások a környéken realizálódnak.

Ezen felül a repülôtér üzemeltetése a közvetlen környék - többnyire a közeli nagyváros - üzemei által a repulötér számára termelt, illetve nyújtott árukkal és szolgáltatásokkal, közvetlenül hozzájárul a regionális gazdaság erósödéséhez.

Az alkalmazottaknak kifizetett bérek és egyéb juttatások a régióban érvényesülö vásárlóerő által - multiplikátor hatásokkal erősödve - kedvezően befolyásolták a gazdasági teljesítöképességet, potenciált, különösen az alkalmazottak lakóhelyein.

Nemcsak a foglalkoztatottak száma, de a pénzbevételek tekintetében is érvényesül a multiplikátor hatás. A repulobtéren bér, fizetés, megbízási dij fejében kifizetett minden DM-ra a német repülőterek régiójában átlagosan 1,63 DM „,következménybevétel" jut. (A frankfurti és a párizsi reptér esetében a koefficiens 1,5.) Ez gyakorlatilag azt jelenti, hogy a repülőtéri tevékenységből keletkező minden egyes márka vagy frank 1,5-1,63-szoros plusz bevételt eredményez a térségben.

A repülőterek környéke általános közlekedési feltárásának javitása a repülőtér környékére gyakorolt közvetett hatásának további elemét képezi. A repülőtér elérésére rendszerint szinte pazarló nagyvonalúsággal kiépített közlekedési pályák (gyorsvasutak, autópályák stb.) további kedvező tényezőket jelentenek a repülötér közelében letelepedő üzemek számára. 


\section{A repülőterek mint a regionális gazdaság tényezői (A repülôterek által teremtett különlegesen keđvező közlekedési helyzet területi hatásai)}

\section{A légi közlekedési hálózatba bekapcsoltság általános előnyei}

Amikor egy város közelében közhasználatú repülötér kezd müködni, egészen ủj helyzetet teremt az elérhetősége tekintetében. Zsákvonalas (kizárólag két település illetve repülótér közötti) helyzet Európában szinte ismeretlen (már a tengeren túli kontinensek gyéren lakott térségeiben is ritka), a vonalak hálózatot alkotnak, tehát (átszállások árán) mindegyik közhasználatú repülötérről el lehet jutni a világ csaknem valamennyi repülöterére.

Igaz, ezzel a lehetőséggel csak azok tudnak élni, akik meg tudják fizetni a viteldijat vagy a légi szállítást. A szárazfơldi és vízi kơzlekedéssel szembeni radikális idôtakarékosság előnyét a népesség adott rétege tudja csak élvezni. Ellenben a vállalatokat, közületeket, intézményeket anyagi okok általában nem akadályozzák a légi szolgáltatások igénybevételénél. A nem kőzhasználatú repülöterek viszont általában csak tulajdonosa és azok számára jelent előnyt az elérhetőségben, a távoli kapcsolatok gyors realizálásában, akik számára a repülőtér használatát (saját és bérelt gépeikkel, térítés mellett vagy ingyenesen) lehetővé teszik. Ilyen formán a nem közhasználatú (magánszemély, intézményi, vállalati tulajdonban lévő), általában csak kis, legfeljebb kőzépkategóriás gépek kőzlekedésére alkalmas repülôterek gazdasági-társadalmi haszna jóval korlátozottabb a közhasználatůnál. (Még a birtokban lévők számára sem mindegy, hogy milyen hatékonysággal tơrténik a légi személy- és áruszállítás; a közhasználatú reptér elỏnye nyilvánvaló.)

Annak, hogy a repülôtér az elérhetôség új minôségét teremti meg a környezỏ települések, egy térség számára, közvetlen anyagiakban mérhetỏ és közvetett, összegszerüen nehezen kifejezhető elönyei vannak.

Pénzben nem vagy alig mérhető hasznot eredményez, de tagadhatatlanul kedvezőbb helyzetet teremt a légi közlekedési hálózatba kapcsolódás a kulturális, tudományos és sportélet tekintetében:

- mivel könnyebben elérhetö, hogy rangos mủvészek, együttesek (színházak, zenekarok, tánccsoportok, kórusok) fellépjenek;

- sportolók, csapatok bekapcsolódjanak nagytérségi, nemzetközi bajnokságba;

- tudományos konferenciák és egyéb olyan tanácskozások számára, amelyek résztvevői távoli térségekben laknak, ugyancsak jóval vonzóbb a repülőtérrel rendelkező, vagy ahhoz közeli település, mivel a magasan képzett szakemberek értékrendjében az időnek különleges értéke van.

A többnyire „pénzben is mérhető" közvetlen gazdasági haszon különbözö formákban képzỏdik. (Errỏl a további részekben lesz szó.)

Ma már a nemzetközi üdulorrégiók sem nélkülözhetik a repülőteret. Számtalan példa bizonyítja, hogy fóként a szigeti fekvésủ üdülőhelyek azóta váltak az üdülni vágyók, turisták seregének célpontjává, a magas szintủ és nagy méretekben kifejlesztett szolgáltatások (az „idegenforgalmi ipar”) szinterévé, amióta nagy teljesítményư repülöteruk van. 
A repülōterek által biztositott közlekedési lehetőségek elónye a térség vállalataira nézve

Korunkban, amikor a termelés fajlagosan egyre kevesebb anyagot, de egyre több információt igényel, és amikor a globalizálódási folyamat eredményeképpen egyfelöl mind nagyobb területre terjed ki, másfelöl mind kisebb egységekre, telepekre bontottan müködik a földrajzi munkamegosztás, és amikor az idő értéke növekszik, valamennyi közlekedésfajta közül a kedvező tulajdonságai (gyorsasága, nagy távolságok megtételére való alkalmassága, elvileg egyenes vonalvezetése, biztonságossága és kényelmessége stb.) miatt a légi közlekedés iránt növekszik a legjobban a kereslet.

\section{Az üzleti célú közlekedés lehetösége}

Üzleti utazások alatt egy alkalmazottnak az üzemi (munkahelyi) elvárások, megbízások teljesítésével, tevékenységével kapcsolatos, munkaidő alatti utazási tevékenységét értjük.

Az üzleti célú, a vállalati ügyintézéssel kapcsolatos légi közlekedés volumenét lényegében a regionális gazdasági tevékenységek mérete és struktúrája, valamint a régiók közötti interakciók intenzitása határozza meg. Az üzleti utazások szükségessége ágazatonkẻnt, üzemenként, intézményenként és foglalkozási csoportonként is differenciálhatóan különbözőképpen alakul. Az a haszon, amit a vállalat, intézmény a légi közlekedés igénybevételéböl húz, nagyon különbözö, és mind munkahelyen belüli, mind külsö tényezök befolyásolják.

Külföldi befektetők körében, amikor telephelyröl döntenek, elönyben vannak a repülötérrel rendelkezö települések, mivel a távoli nagyvállalati központból végzett (gyakori személyes látogatásokkal, helyszínen történö konzultációkkal járó) operatív irányítást nagymértékben megkönnyíti a gyors közlekedés.

A termelési kooperációval kapcsolatos szállítási igények

Nagy értékủ félkészgyártmányoknak, részegységeknek, alkatrészeknek a végterméket elöállító, összeszerelö üzembe szállítása nagy távolságokra egyre gyakrabban légi úton történik, gyakran a raktározás kiiktatására irányuló ún. just in time termelési rendszerek keretében. Ezek müködését nagymértékben elösegíti a légi közlekedés az idóben pontosan ütemeztethetõ szállitásokkal.

Gépek, berendezések szervizelése

Nagy értékủ gépek, müszerek, müszaki berendezések között elég sok az olyan, amelyek garanciális, söt azon túli szervizelését, pótalkatrész ellátását a márkavállalat közvetlenül és nem a kihelyezett részlegével látja el. A szerelök és cserealkatrészek gyors szállitása nagyobb távolságra a leggyorsabban repülögéppel történik (pl. kủlföldról származó mezőgazdasági gépek aratáskori meghibásodása vagy autógyári gyártósor tönkremenése esetén gyors beavatkozásra van szükség).

$\mathrm{Az}$ elöbbi és egyéb körülmények miatt a világgazdaságba bekapcsolódó modern üzemek többsége számára az elfogadható távolságban lévő repülôtér az adott térség infrastrukturális állományának nagyon fontos részét képezi, sỏt egyesek számára 
ma már elengedhetetlen feltételt jelent. A repulötér jelentősége, az arra való ráutaltság mértéke természetesen szakmától (ágazatoktól), üzemnagyságtól és a vállalatok részlegeinek térbeli szerveződésétől függöen változik.

A repulőterek közlekedési ,állomásként”, az általuk teremtett különleges közlekedési-szállítási lehetőséggel regionális és összgazdasági jelentőségü hatással vannak más vállalatok teljesítményére, értéktermelésére és szolgáltatásaik értékesítésére is.

\section{A repülőterek összeköttetés teremtésbeli jelentỏségének mérése}

A repullötér, a légi utazások jelentőségét az adott térség gazdaságának és más tevékenységeinek mükðdtetésében többféle mutatóval lehet érzékeltetni. A legjobban használható egy olyan viszonyszám, amely a külföldre repülögépen utazók számát a régióban foglalkoztatottak számához viszonyítja.

Az e mutató segitségével az NSZK-ban 1992-ben végzett klaszteranalízis nagy különbségeket mutatott ki a repülötér-állományban:

- a legintenzívebb repülési igény Frankfurt, Düsseldorf, Hamburg, München, Wienbaden-Mainz repterek régióját jellemzi (magas, 4,0944-es átlagos klaszterértékekkel);

- közepes feletti $(0,1948)$ érték Hannover Bréma és Lübeck repterek régióit jellemezte;

- átlag alatti $(-0,0889$ átlagértékü) intenzitás jellemezte Nürnberg, Augsburg, Karlsruhe, Mönchengladbach, Köln, Darmstadt, Aachen és további öt kisebb reptér régioját;

- gyenge intenzitás jellemezte Bayreuth/Hof repülötér régioját (-0,5730 klaszter indikátor értékkel) az összes többi a nemzetközi repullésben jelentéktelen reptér régióját erősen negativ értékek (átlagosan -0,2435) jellemezték (mint pl. Essen, Dortmund, Bochum esetében).

Annak a pozitiv tulajdonságnak a mérésére, hogy milyen lehetőségeket biztosit a repülötér a nemzetközi (személyesen gyakorolt) kapcsolatok kialakításához és ápolásához, jól használható egy másik indikátor, amely az adott reptérről közvetlenül elérhető külfơldi célok számát adja meg.

Ezen az alapon az NSZK-ban a repterek közül:

- Frankfurt vezet (8,8364-es klaszterrel), majd

- Dusseldorf, Wiesbaden/Mainz, Bonn és Darmstadt következik (1,4842 átlaggal), ezután jön

- Köln, Wuppertal, Essen, Dortmund, Bochum (0,1725-ös alacsony értékkel).

- Összesen 6 klaszternek van negatív átlagértéke. A legkedvezőtlenebb régiók: Würzburg, Kiel, Göttingen, Kassel, Regensburg, Hameln és Rosenheim, együttesen 0,3399 -es középértékkel.

Az előzőekben bemutatott, valamint egyéb indikátorok értékei alapján kirajzolhatók a nemzetközi légi közlekedési összeköttetések szempontjából kedvezö és kevésbé kedvező helyzetben lévő repülöterek. Ezek általában a „magas metropolizációs illetve centralitás értékü" (azaz nagyváros-világvárosi és a központi funkciók gyakorlásában kitünő) térségekhez kötődnek, amelyekre a népesség átlag feletti képzettségi színvonala és a szolgáltatási szektor fejlettsége, magas reprezentációja a jellemző.

Baden-Württemberg tartomány (ezen belül is Stuttgart, Mannheim és Heidelberg térsége) az 1970-es évek végétöl kitünt dinamikus fejlettségével (kủlönösen az informatikai eszközök gyártása és egyéb csúcstechnikai iparok megtelepedése tekintetében), melyben a kedvezö légi közlekedési lehetőségeknek igen előkelő szerepe volt (a közeli stuttgarti, frankfurti repülöterek jóvoltából). 
A repülöterek mint telephelyek (A repülöterek mellé települt vállalatok, üzemek)

A repülöterek üzemelésük révén, mint vonzó, jó adottságú, egyre értékesebbnek tartott telephelyek is nagy hatással vannak egy régió gazdasági fejlödésére. Amennyiben a vállalatok a repülöterek mellett vagy közvetlen közelükben telepednek le, különleges elönyökre tehetnek szert.

A repülőterek és az általuk közvetlenül kiszolgált szomszédsági gazdálkodó cégek „egymásra találása” kétféle módon történik:

- általában a meglévő repülőtér mellé idővel betelepednek az üzemek, de

- a müködő szállitásigényes nagyüzem mellé is telepedhet repülőtér (mint pl. Kanadában, Oroszországban az urán- és más ércbányák mellé).

A legkézzelfoghatóbbak azok a közvetlen növekedési hatósok, amelyek a szomszédban elérhető légi közlekedési szolgáltatások igénybevételéből adódnak a vállalatoknál. A szállitások idejének lerövidítése, megbízhatóbbá válása, esetleg olcsóbbá válása révén, valamint azáltal, hogy általuk lehetôség van az értékesitési és beszerzési piacok kibövitésére, növelik a repülöterek az alkalmazott termelési tényezők teljesítőképességét. A legfontosabb kedvezỏ hatások a légi szállítást legjobban igénybe vevő vállalatoknál azok a költségmegtakaritások, amelyek a más repülőterekre vagy azok közelébe valamilyen földi közlekedési eszközzel való szállítás elkerüléséböl (ez a mozgatásra, rázkódásra nagyon érzékeny áruk esetében fontos), valamint az üzleti ügyben utazók és a légi szállitás igénybevételével kapcsolatos időmegtakaritásból adódnak. Az időmegtakarítás a teherszállitásban, sok esetben nagyon magasra értékelt tulajdonság. A 3. táblázatba foglalt adatok illusztrálják, hogyan alakul a megtakarított idő értékének nagysága.

\section{TÁBLÁZAT}

Néhány példa a légi áruszállitás révén megtakarított szállitási időböl eredö haszon mértékére

(Some Example for Benefits Derived from the Shorter Term of Transportation due to Air Transportation)

Elsö példa: Frankfurt-London viszonylatban

\begin{tabular}{|l|c|c|c|}
\hline \multicolumn{1}{|c|}{ Tételek } & $\begin{array}{c}\text { Mérték- } \\
\text { egység }\end{array}$ & $\begin{array}{c}\text { Közúti szállí- } \\
\text { tás }\end{array}$ & $\begin{array}{c}\text { Légi teher- } \\
\text { szállítás }\end{array}$ \\
\hline Árukezelési idö (közlekedési, vámolási) & óra & 24 & 24 \\
\hline Odaszállítás", átrakás & óra & - & 8 \\
\hline Közlekedési idő ** & óra & 17 & 1 \\
\hline A szállításra fordított összes idö & óra & 41 & 33 \\
\hline Távolság & $\mathrm{km}$ & 750 & 660 \\
\hline Szállítási ár tkm-enként ${ }^{* * *}$ & $\mathrm{DM} / \mathrm{km}$ & 0,12 & 0,73 \\
\hline Szállítási ár tonnánként & $\mathrm{DM}$ & $90,-$ & $482,-$ \\
\hline Szállítási árkülönbség & $\mathrm{DM} / \mathrm{t}$ & \multicolumn{2}{|c|}{$392,-$} \\
\hline Szállítási idökülönbség & óra & \multicolumn{2}{|c|}{$89,-$} \\
\hline Az egy órára jutó szállítási árkülönbség & DM/óra & \multicolumn{2}{|c|}{} \\
\hline
\end{tabular}


Második példa: Hamburg-Jeddah (Dzsidda) viszonylatban

\begin{tabular}{|c|c|c|c|}
\hline Tételek & $\begin{array}{l}\text { Mérték- } \\
\text { egység }\end{array}$ & $\begin{array}{c}\text { Tengeri szál- } \\
\text { lítás }\end{array}$ & $\begin{array}{l}\text { Légi teher- } \\
\text { szállítás }\end{array}$ \\
\hline Árukezelési idő (közlekedési, vámolási) & óra & 24 & 24 \\
\hline Odaszállítás", átrakás & óra & 24 & 24 \\
\hline Közlekedési idő $^{* * * *}$ & óra & 480 & 8 \\
\hline A szállításra fordított összes idő & óra & 528 & 56 \\
\hline Szállítási ár tonnánként & $\mathrm{DM} / \mathrm{t}$ & $403,-$ & $3980,-$ \\
\hline Szállítási árkuulönbség & $\mathrm{DM} / \mathrm{t}$ & \multicolumn{2}{|c|}{$3577,-$} \\
\hline Szállítási idókülönbség & óra & \multicolumn{2}{|c|}{472} \\
\hline Az egy órára jutó szállítási árkủlönbség & DM/óra & \multicolumn{2}{|c|}{7,58} \\
\hline
\end{tabular}

"Az árunak a szállítóeszkozhoz (teherautó, repưlógép, hajó) való eljuttatásához szulkséges idó.

* Átlagos sebesség $60 \mathrm{~km} / \hat{o}$; a kozlekedési idö magában foglalja a be- és kirakodási idót is;

-.* A teherautó jellegzetességei: 38 t ơnsúly, 25,3 thasznos súly, 80\%-os kihasználtság, évi teljesitménye 110 ezer km, 2 gépkocsivezetó;

"**** Hamburg-Jeddah teherhajóval 20 nap;

"**** Szállitási költségek fúggnek a súlytól és a súly-terjedelem arányától. Pl. feltételezzuk, hogy mindkét szállításfajta számára egy emelövillás targoncával mozgatható teheráru-darab 1 tonna súlyú és $2 \mathrm{~m}^{3}$ terjedelmú. A hajóval való szállitási dij 140 dollár, hozzászámítva 13\% raktári pótlékot is. Azonos súlyterjedelem viszony és azonos súly esetén a légi szallítás egy $\mathrm{kg}$-ra számitott dija csupán 1/6-dal kerul tơbbe a tengerinél.

Forrás: Légitársaságok adatközlése.

A példák azt mutatják, hogy a szállitási idóegységre (az egy órára) jutó árkủlönbség a célországok és az összehasonlító kőzlekedési eszközök szerint ìngadozik. Az a magas érték, amely a megtakarított órákra a kevésbé értékes áruknál, pl. gépkocsialkatrészeknél kalkulálható, arra utal, hogy sokszor nemcsak az áru értékét, hanem az alkalmazási helyén való felhasználásának célját és azokat a körủlményeket is, amelyek miatt az áru légi szállítására elengedhetetlenül szủkség van, figyelembe kell venni. Ide vonatkozóan a következő tipikus esetek illetve szállítmányok hozhatók fel példaként:

- olyan javak gyors eljuttatásakor, amelyek hiánya a termelés folyamatosságát veszélyezteti, termeléskiesést okozva;

- olyan javak szállításakor, amelyeket szárazföldi vagy vízi úton nem lehet határidöre garantáltan a fel-, illetve a bedolgozásuk helyére szállítani, és ezért a pontos határidökhöz kötött szállítási szerződés megszegése folytán a nagyơsszegủ büntetések elkerülése érdekében a drágább szállítás is gazdaságos;

- azoknak a javaknak a szállításakor, amelyeknél alapvetỏ kỏvetelmény, hogy biztonságosan eljussanak céljukba - ilyenek például a nagy értékü és érzékeny áruk.

A repülöter ek telephely értékét egyre jobban felismerve a légikikötők környékén elöszeretettel települnek meg nemcsak aviatikai ipari üzemek (repülőgép- és helikoptergyárak, alkatrészgyártó és gépjavító uzemek), hanem olyan kis anyagigényü, de értékes termékeket előállító ủzemek is, amelyek számára különös fontossága van a légi szállítás lehetőségének (mind az alkatrészek beszállításában, mind a késztermékek elszállitásában). Ilyenek elsősorban a számítástechnikai hardvert, chippeket 
gyártók, gyémántcsiszolók, ékszerkészítők stb. A fejlett országok modern repülötereit valóságos ipari parkok veszik körül nagy hozzáadott értéket elöállitó új generációs ipari létesitményekkel.

A repülőterek telephelyeinek értékét jól fémjelzi a környékükön újonnan létrehozott üzemek száma (a foglalkoztatottak számával, a termelési értékekkel súlyozva) és a más térségekböl történö üzem- és vállalati központ áthelyezödések folyamatának erőssége.

A legutóbbi évtizedekben, a fejlett országokban figyelemre méltó „átköltözések” történtek a sokirányú összeköttetést biztositó nagy repülóterek közelébe

- akár országot is váltva (pl. London-Heathrow vonzásának eredményeként), több európai és amerikai világcég létesített elektronikai, csúcstechnológiai üzemet a Londonból NY-ra vezetổ A8-as autópálya mellett, de az új müncheni repülötér mellé is átköltözött néhány kullföldi üzem;

- gyakoribb azonban, hogy az országon belül a régi telephelyekröl történik az üzemek áftelepülése a repülótér mellettihez.

Németországi, brit és amerikai tapasztalatok szerint többféle cég is keresi a repülötér közelségét, „tapad” előszeretettel a légi közlekedés központjaihoz, pl.

- a külföldi tulajdonú üzemek, lerakatok, amelyek kamatoztatni tudják a vállalatkőzponttal, irányítócentrummal való közvetlen légi összeköttetés elönyét,

- a nagy belföldi kereskedelmi társaságok,

- a nagy vállalati igazgatási központok.

A legújabb időkre - különösen Nagy-Britanniában és Észak-Amerikában - nemcsak az iparterületek létrehozása jellemzó, hanem a vállalati föigazgatóságok, csúcskőzpontok mind nagyobb számú megjelenése is a repülöterek abszolút és viszonylagos értelemben vett közelében (pl. Atlanta nemzetközi repülőtere valóságos koncentrációja az ilyen központoknak):

- az igen rangos, nemzetkőzi piacon tevékenykedő szolgáltató üzemek,

- az erösen exportorientált üzemek (még a közepes nagyságúak is) legalább az értékesitési részlegüket vagy a központjukat igyekeznek repülöterekhez áthelyezni.

A nagyvállalatokon belül tendenciaszerủvé vált a termelés és az igazgatás teruleti elkủlönülésével az irányító funkcióknak a kiemelkedő teljesítményü repülőterekkel rendelkező nagy agglomerációk központjaiba való áthelyezódése. Mennél intenzívebb egy üzemnek a telephelyi kötódése a repülötérhez, annál mélyrehatóbbak a repülötérre tartó hosszas utazásnak a pénzbeli és időbeli ráfordításban kifejeződő kedvezótlen hatósai.

Az üzemáthelyezések száma még mindig kevesebb a gazdaságossági szempontból kívánatosnál, ami a meglevő vállalati struktúrák tehetetlenségi erejének hatására vezethetö vissza. Az elidegenedett részvénytársaságok számának növekedése következtében azonban gyengül a telephelynek egy bizonyos helyhez ragaszkodása, melynek alapja a személyes kötődés (pl. a hagyománytiszteló családi vállalk əzások tulajdonosának a szülőhely iránti igen erős vonzalma) volt. Ezáltal sokkal könnyebben végbemehet a vállalatok vagy vállalatrészek áthelyezése az eredeti telephelyröl, amelyekhez korábban személyes okokból ragaszkodtak. E lépések részét képezik 
annak a sokösszetevős folyamatnak, amelynek eredményeképpen a periférikus telephelyek tovább gyengülnek, és a nemzetközileg jelentős, sürün települt nagykiterjedésü agglomerációk, mint termelési struktúrájukban átalakult iparvidékek, tovább erösödnek. A vállalatok elvárják, hogy egy nemzetközi szinten is versenyképes térséghez tartozzék repülötér, amely a vállalat munkatársainak lehetővé teszi, hogy a több vagy éppen sok országra kiterjedö, szerteágazó nemzetközi tevékenységüket egyre nagyobb mértékben megfelelö légi összeköttetések útján személyesen koordinálják.

Az áthelyezódéseknek nemzetgazdasági szinten mutatkozó gazdasági elônye is van azáltal, hogy növekszik a nemzetgazdaság valamelyik fontos szektorában a hatékonyság a telephelyek ésszerübb, a termelékenységet növelö allokációja következtében.

\section{A repülőtér mint termelési tényezö értéke}

A vállalkozók tevékenységének számos külsõ feltétele között elôkelõ helyet foglalnak el a közlekedési-tóvközlési lehetőségek, amelyek súlya és fajtája azonban a konkrét gazdasági- és közlekedés-földrajzi helyzettől, illetve az adott régió gazdasági szerkezetétöl függ.

Így pl. az erősen iparosodott Közép-Angliában, amikor a Leeds-Bradford regionális repülötér fejlesztésének tervezésekor közvélemény-kutatást végeztek az üzleti életben tevékenykedōk körében, kiderült, hogy a legfontosabbnak a jó közúti kapcsolatot tartották az ország minden részével (ehhez egyébként minden lehetóségük megvolt, mivel autópályával kapcsolódik a térség az országos hálózathoz), majd a 2. és 3. helyen "holtversenyben" az országgal való jó vasúti összeköttetést, illetve a fejlesztés elōtt álló LBA reptérról kiinduló, jó légi összeköttetést emlitették ,"nagyon fontos"-nak, ez utóbbit inkább a nemzetközi kapcsolatok szempontjából. A kikötők kivételével a közlekedést a vállalkozók sokkal fontosabb termelési tényezỏnek itîliték meg 1990-ben, mint az dizleti/pénzügyi szolgáltatásokat, vagy a pénztámogatást és a financiális ösztönzést (holott korunkban a területfejlesztésben az utóbbi tényezök helyi értéke igen magas), vagy pl. a lakásellátottságot és az iskolai képzést (4. táblázat). Mivel a válaszokból az is kiderült, hogy az ország peremterületével való összeköttetés csak szerény százalékos arányban jelent meg a „nagyon fontos" kategóriában, az üzletemberek a repülôteret minden bizonnyal inkább a nemzetközi, mintsem az országon belüli kapcsolatok szempontjából tartották fontosnak.

\section{TÁBLÁZAT}

A közvélemény-kutatás eredménye az egyes kommunikảciós lehetôségek javitásának lehetõségérốl Leeds-Bradford térségében 1990-ben (\%)

(Outcome of the Survey on Possibilities of Improvement of Communication Opportunities in the Area of Leeds-Bradford in 1990)

\begin{tabular}{|l|c|c|c|c|}
\hline \multicolumn{1}{|c|}{$\begin{array}{c}\text { Kommunikációs alágazat, } \\
\text { probléma }\end{array}$} & $\begin{array}{c}\text { Nagyon } \\
\text { fontos }\end{array}$ & $\begin{array}{c}\text { Kevésbé } \\
\text { fontos }\end{array}$ & $\begin{array}{c}\text { Nem } \\
\text { fontos }\end{array}$ & $\begin{array}{c}\text { Nem } \\
\text { tudja }\end{array}$ \\
\hline Autópálya / fót fejlesztés & 65,6 & 29,9 & 3,9 & 0,8 \\
\hline Kikötỏ fejlesztés & 12,8 & 47,3 & 36,5 & 2,7 \\
\hline A forgalom csökkentése & 69,1 & 24,3 & 5,3 & 1,3 \\
\hline $\begin{array}{l}\text { A Leeds-Bradford repủlőtér } \\
\text { fejlesztése }\end{array}$ & 48,4 & 31,4 & 19,6 & 0,7 \\
\hline A vasúti szolgáltatások fejlesztése & 40,5 & 43,8 & 14,4 & 4,3 \\
\hline A távközlés fejlesztése & 30,9 & 55,0 & 10,7 & 3,4 \\
\hline
\end{tabular}

Forrás: CAA. 1993. 
Egészen más képet eredményezett, amikor a szóban forgó felmérés keretében arra keresték a közvélemény-kutatók a választ, hogy a megkérdezettek (már nemcsak az üzletemberek, hanem a széles közönség) a közlekedés melyik fajtájának a fejlesztését tartják fontosnak, illetve mi a véleményük a fejlesztésröl. Kiderült, hogy a legtöbben a forgalom csökkentését tartják a legfontosabbnak („zöld gondolkodás”-ról téve tanúságot), akik viszont a fejlesztések mellett vannak, azok körében az autópálya- és foút-fejlesztések hívei vannak tőbbségben, és csak (jóval kisebb arányban) a második helyen említik nagyon fontosnak a repülötér fejlesztését (de még mindig tőbben tartották nagyon fontosnak, mint a vasút, sỏt a távközlés fejlesztését). Ebből arra lehet következtetni, hogy a repülobtér akkori szolgáltatásai kielégítették a lakosság nagy részének igényeit. (A kőzúti közlekedés ilyen-olyan mértékben mindenki számára fontos, a regionális repullőtérről indult meglehetősen drága járatokat pedig sokan nem igénylik. A lakosság szélesebb körében inkább az interkontinentális - ritkán történő rokonlátogatással, udüléssel kapcsolatos - repülés iránt van csak érdeklődés.) (5. táblázat)

\section{TÁBLÁZAT}

A különféle tényezök fontossága a helyi gazdasági-üzleti élet számára Közép-Angliában 1990-ben (\%)

(Importance of Various Factors for the Local Business in Middle England in 1990)

\begin{tabular}{|c|c|c|c|c|}
\hline Termelési / îzleti tényezők & $\begin{array}{c}\text { Nagyon } \\
\text { fontos }\end{array}$ & $\begin{array}{l}\text { Eléggé } \\
\text { fontos }\end{array}$ & $\begin{array}{l}\text { Nem } \\
\text { fontos }\end{array}$ & $\begin{array}{l}\text { Nem } \\
\text { tudja }\end{array}$ \\
\hline $\begin{array}{l}\text { Az ország peremterületével való } \\
\text { összekőttetés }\end{array}$ & 16,9 & 52,0 & 27,0 & 4,1 \\
\hline Szórakozási / sport lehetőségek & 15,9 & 53,1 & 26,9 & 4,1 \\
\hline Jó közúti kapcsolatok az országban & 84,6 & 12,1 & 2,0 & 1,3 \\
\hline Jó vasúti összeköttetés az országban & 73,3 & $22 ; 0$ & 3,3 & 1,3 \\
\hline Jó légi ősszeköttetés az LBA-ról & 73,3 & 23,3 & 2,0 & 1,3 \\
\hline Pénztámogatás / financiális osztönzés & 45,9 & 42,5 & 8,2 & 2,7 \\
\hline Üzleti / pénzügyi szolgáltatások & 35,9 & 52,1 & 7,7 & 4,2 \\
\hline Jó és olcsó lakások & 35,1 & 54,1 & 7,4 & 3,4 \\
\hline Jó iskolák / kollégiumok & 47,6 & 41,4 & 8,3 & 2,8 \\
\hline Kvalifikált gyakorlott munkaerő & 63,9 & 25,0 & 7,6 & 3,5 \\
\hline Jól elérhető kikőtỏ & 30,9 & 47,1 & 14,7 & 6,6 \\
\hline
\end{tabular}

Forrós: CAA. 1993.

A regionális-interregionális viszonylatủ légi közlekedés helyett a gépkocsit vagy a vonatot elsősorban azért részesítik előnyben az emberek, mert azok jóval gyakrabban rendelkezésre állnak. Másodsorban jelentös befolyásoló tényező, hogy az utazásra fordítandó teljes idỏ repuilőgép választása esetén sem lényegesen rövidebb (az általa megtakarítható idő nem igazán nagy). Az ár, azaz a fóldi közlekedés olcsóbb volta csak a negyedik helyen szerepelt az indokok között.

Ezek a tényezők nem csupán Közép-Anglia egy meghatározott térségére, hanem tulajdonképpen hellyel-közzel érvényesek Európa nagy részére is. Másként vetödik fel az ár pl. a harmadik világbeli nyomorrégiókban (ahol csak kevés ember számára elérhetó a repưlógépes utazás), és egészen másként a ritkán, de jómódú emberek által lakott Alaszkában, ahol az árnak nincs különösebb szerepe a közlekedési eszköz választásakor, annál inkább az időráfordításnak és a kényelemnek. 


\section{A repülōterek gazdasági hatása a régiókra}

A repülötér által a környező térség gazdaságában kiváltott hatások jelentős része áttételekkel érvényesülö, ezért nehezen mérhető, meghatározható. $E$ hatások a „közlekedési rendszerek alakítóereje” és a közlekedésnek „más gazdasági egységekre gyakorolt telephelyképzö ereje" fogalmakkal írhatók körül. A repülöterek különböző funkciói térségeket formáló hatásainak módja és intenzitása messze nem egyforma. Már aszerint is különbözik, hogy a belföldi vagy a nemzetközi, menetrendszerủ vagy a charter közlekedés, a személy- vagy a teherszállítás van-e túlsúlyban szolgáltatásaikban. A személyszállító charter repülőterek alapvetően a külföldi turizmust, a külföldi üdülőhelyekre való tömeges utasszállítást szolgálják, ezért nincs telephely értéket növelö hatásuk, ellentétben az árufivarozásra specializált repülőterekkel, amelyek a legjobban vonzzák a légi szállításra utalt üzemeket.

Az új közlekedési eszkőzök és -pályák, így a légi összeköttetések is képesek feltárni a területhasznositás új lehetőségeit, és ezáltal impulzusokat, ösztönzést adni a területi fejlődés számára. A repülőterek az általuk kiszolgált járatcélpontok száma és jelentősége alapján (egyaránt) teremtenek új potenciálokat a környéken letelepedő üzemeknek, és tárnak fel a régióban meglevő potenciálokat az új használók számára. A légi közlekedés meghosszabbitja a régióban termelt termékek, javak "hatótóvolságát", azaz térben kitágítja piacterületüket. Az igy javuló értékesítés általában a termelés növekedése által a határköltségek csökkenéséhez vezet. Ezek éppen úgy, mint a beszerzés optimalizálása az egyes üzemek gazdaságosságának növekedését, és ezzel a régió, végső soron a gazdaság teljesítményének növekedését eredményezik. Néhány - részben újonnan keletkezett - régióbeli szolgáltatási ágazat számára csak a légi közlekedés használata teszi lehetôvé a gazdaságossághoz elegendõ nagyságú kereslet keltését, a régión túli integrációs hatásokat.

A térbeli hatások terén a repülőterek regionális növekedési pólusokat képeznek, mivel egy nemzetközi repülötér létezése fejlesztőleg hat új üzemek, intézmények letelepedésére, a növekedni képes iparcsoportok, húzóágazatok kialakulására, fenntartására és továbbfejlỏdésére. Különösen az elektrotechnika, a számítástechnika, a finomgép- és mủszergyártás, a sokféle tanácsadás és a szabad foglalkozások vonzódnak a légi közlekedéshez.

A repülőtereknek a térségek gazdasági életét formáló ereje különböző nagyságrendú (léptékü) szinteken fejeződik ki:

- Kistérségi-helyi szinten az ipari területek és ipari parkok a nagy légi közlekedési affinitású ủzemeket vonzzák.

- Középtérségi szinten, amikor el kell dönteni, hogy két agglomeráció közül melyiket válasszák telephelyül, előnyben részesül a teljesitőképes repülőtérrel rendelkező, azaz ennek a javára döntenek.

- Nagytérségi szinten a repuilőtér a térség infrastrukturális „berendezésének”, ellátottságának olyan „magától értetődő”, fontos tényezőjét képviseli, amely nélkuil a nemzetközi tevékenységet folytató vállalatok a letelepedésröl lemondanának. A nơvekvơ koncentrációs tendenciák és az ennek következtében a 
betelepülő nagyobb új üzemeket befogadó, gazdaságilag jelentős agglomerációk közötti verseny következtében, a repülötér nélküli, sürün települt nagy iparvidék hátrányban van a fejlődési lehetőségei tekintetében. Ez még inkább így van a posztindusztriális korban, amikor a hagyományos telepítő tényezőkhöz, erőforrásokhoz, tehát egy bizonyos fizikailag meghatározott telephelyhez kötődés csökkent (pl. nem követelmény már a fütőanyag és a nyersanyag közelsége) és ezáltal a telephelyváltozatok száma (amelyekböl a vállalat választhat) növekedett.

Ugyan a légi közlekedést, mint kifejezett távolsági közlekedési rendszert a régiók számára csupán külső összeköttetésekre használják (régión belül csak ritkán), a távolsági közlekedési vonalakhoz való csatlakozás megteremti a feltételét a gazdasági előnyök jobb kihasználásához más régiókban.

A más gazdasági terekhez a légi úton csatlakozás által keletkezỏ régión belüli kedvezö hatások kibontakozása, területi elterjedése mindenekelött a repülötérnek a földi közlekedési hálózatba való bekötésétól függ. Tény azonban, hogy bármennyire is irányuljon a regionális földi közlekedési rendszer a repülötér felé, lehetővé téve annak közvetlen elérését, egy repülötér nem tud olyan mértékben hozzájárulni a telephelyek szóródásához, mint a vasút vagy a közúti közlekedés, mivel a repülötértől növekvő távolsággal, valamint a további átrakodásokra való ráfordítás miatt elvész a légi közlekedés elönyeinek egy része.

A gazdas ági tevékenységek globalizálódásának korában a régión túli közlekedési elérhetöségnek növekvó jelentősége van, mivel képes regionális növekedési és struktúrajavitó impulzusokat kiváltani azáltal, hogy a légi összeköttetések kínálatával a repülötér elönyös helyzetet teremt az exportorientálttá váló gazdasági vállalkozások számára, és erósiti a régió globális versenyképességét.

A régió gazdaságának a repülőtérből olyan előnye származhat, hogy az üzemeinek

- lehetőségük nyílik a piac bővitésére,

- a ráfordításaik csökkentésére,

- az olcsóbb nyersanyagforrások feltárására,

- a képzettebb munkaerő vonzására, megszerzésére.

Az ilyen előnyöket élvező (ezáltal a termelékenységüket, hatékonyságukat és versenyképességüket növelő) üzemek az elért nagyobb nyereségből bővítik kapacitásukat, beruháznak, ezzel gazdagítják a régió gazdasági potenciálját, növelik versenyképességét. Ugyanilyen hatása van a régiókba más térségekböl áttelepülő üzemeknek is.

A nemzetközi kapcsolatok bỏvülésével, az innovációk gyorsabb terjedésével a gazdasági szerkezet korszerúsödése többféle módon nyilatkozhat meg azáltal, hogy megnyílnak a specializáció és a diverzifikáció lehetőségei. A modern korban változóban vannak a telephelyi követelmények. Amíg a klasszikus ipari társadalomban egy valamire való ipartelep szinte elképzelhetetlen volt vasúti kapcsolat nélkül, ma már az ipari termékekben az anyagi összetevök viszonylagos jelentőségvesztése, ugyanakkor az információ hányad növelése, a müszaki, szervezeti és területi változások egymást kölcsönösen erősítỏ dinamikáját eredményezik. $A z$ új, innovatív termelési módok kibontakozásában a légi közlekedésnek jỏval nagyobb a szerepe, 
mint más közlekedésfajtáknak. Ezzel a regionális fejlödés szereplöi között egyre rangosabb helyet foglal el.

Egy olyan közforgalmú repülótér, amely a világ nagy agglomerációival, metropoliszaival légi összeköttetésben van, nem jelentéktelen térségi fejlesztési potenciált képez, amely más kedvező tényezőkkel egyưtt az üzembővülések és új üzemek letelepedése által a környék gazdaságát stabilizálja és a növekedését elösegíti.

$\mathrm{Ez}$ a térségalakító erō a nemzetközi repülôtereket egyrészt kistérségi növekedési pólussá teszi, amelyben sok helyen a reptér környéken keletkezö iparterületeken és ipari parkokban a felfejlôdỏ ágazatok szolgáltató- és termelöuzzemei telepednek meg. Másfelöl egy sürün lakott, nagy agglomeráció csak akkor versenyképes, ha ez a térség a közlekedési feltárás, a telekommunikációs infrastruktúra és a különböző kapcsolatbeli elönyổket teremtó távolsági eszközök terén legalább a megfeleló alapberendezettséggel, ellátottsággal rendelkezik.

Atlanta vagy Manchester régió példái azt mutatják, hogy egy nagykapacitású nemzetközi repülōtér kiépitése jelentös tényezöjét képezheti a sikeres, nagyobb léptékü, milliónál több lakost érintő regionális fejlesztésnek. A nagy teljesitoóképességü repülötérrel való ellátottság képes differenciálni a városi agglomerációk fejlõdését.

Pl. Düsseldorf nem kis részben a repülőterének köszönheti, hogy át tudta alakítani hagyományos, túlnyomóan a nehézipar által uralt szerkezetét, míg pl. a hasonló nagyságrendủ Bielefeld régió saját repülőtér hijản erre képtelen volt, elavult struktúrája konzerválódott.

\section{A repülöterek (regionális) vonzáskörzetének meghatározása}

Egy repülőtér területi hatásainak leírásához és elemzéséhez szükség van a vonzáskörzetének lehatárolására. Mivel a repülöterek egyes hatásainak hatósugara különböző, célravezetỏ különböző térségeket lehatárolni a repülőterek hatásainak kimutatására. A legfontosabbak:

- a repuloltér környezeti hatásainak vonzáskörzete,

- a repulötér mint gazdasági tényező vonzáskörzete és

- a repulobtér mint telephelytényezó vonzáskörzete.

$A$ három minóség függetlenitōdhet egymástól. Pl. a repülötér mint vállalat gazdaságossága vagy deficitje nincs hatással a repülötérnek más vállalatoknál érvényesülő hatására, azaz a repülőtér mint telephelytényező vonzáskörzetére.

A környezeti hatások (mint pl. a zaj) alapján lehatárolt körzetek a gazdasági és telephelyi szempontúhoz képest viszonylag szükek, kisebb térségre kiterjedőek. Ez elsősorban abból adódik, hogy a környezetszennyező́k nagytérségi hatásait eddig nemigen kutatták. Ezenfelül e hatásterület megállapítása szempontjából a repülóterek kevésbé fontosak, mint maga a légi közlekedés. A repülőterek környezeti hatásainak lehatárolásához mind a megváltozott területhasználatot, mind az emissziós értékeket figyelembe kell venni. Más közlekedésfajtákhoz hasonlóan a légi közlekedésnél is a kulönbözỏ emisszióterhelésủ területsávok, zónák jól szerkesztett izovonalak segítségével ismertté tehetők, ábrázolhatók.

A repulötér mint gazdasági tényezõ vonzáskörzetét a közvetlen és közvetett foglalkozási hatásai határozzák meg. A közvetlen foglalkoztatási hatás a repülőtér területén foglalkoztatottak a környéki települések lakónépességéhez viszonyitott hányada alapján mérhetö. (Tehát, hogy mennyien dolgoznak a környéki települések 
népességéből a reptéren.) A kőzvetett hatás kimutatásához további mérőszám lehet, hogy milyen mértékben eredményez a repülötér a környezö községekben olyan beruházásokat, amelyek a repülötér építésével vagy müködésével kapcsolatosak.

Ezt az ideális vonzáskörzet lehatárolási módszert azonban a kistérségi szinten szuikséges megfelelö adatok hiánya miatt csak ritkán lehet alkalmazni.

A gazdasági hatásoknál is problematikusabb a repülỏterek telephelyhatásainak operacionalizása. Ésszerủ mérőszám lehet azoknak az üzemeknek a telephelysürủsége, száma, amelyek a telephelyválasztásuknál figyelembe vették a repülötér létét, illetve az általa létrehozott egyéb infrastruktúrát, továbbá azoknak az üzemi alkalmazottaknak a száma, akik a repülötér szolgáltatásait rendszeresen igénybe veszik.

A gyakorlatban azonban az ilyen felmérést nehéz megvalósítani az adatvédelmi törvények és a vállalatok felvilágosítási készségének gyakran tapasztalt hiánya miatt. Ennél könnyebben kivitelezhetó a járatok utaslistáiból utólagosan készített honnan - hová kérdöives felmérésnél a statisztika az ủzleti célból utazókra szorítkozik. Ez a felmérés, valamint a járatok és magángépek útvonalak szerinti megoszlása is elfogadható információt adhat a repülőtér telephelyhatásának területi kiterjedésérỏl.

A kis regionális repülőterek és a rendszertelenül használt leszállóhelyek telephelyhatásáról alig léteznek konkrét információk.

Feltételezhetó azonban, hogy az olyan periférikus térségekben, ahol hiányoznak a nagyobb repülőterek, még a kis repülótereknek is számottevỏ telephely hatása lehet (pl. Németországban Bayreuth, Hof), de a nagy agglomerációk peremén is lehet létjogosultságuk (pl. Dortmund), annak ellenére, hogy az agglomeráció több nagy repülötér (Köln/Bonn, Düsseldorf) is kiszolgálja.

Számszerinti értelemben a vonzáskörzet az a terület, ahonnét az adott repülötérre érkezỏ utasok és áruszállítmányok származnak, ahonnét indulnak. Elosztási terület pedig az a terület, ahová a repülötérről induló utasok és szállítmányok eljutnak.

A kétféle térség általában a gyakorlatban kiterjedésében nagyjából megegyezik, de a forgalom intenzitásában, különösen a teherforgalomban már számottevőek lehetnek a különbségek (pl. légi úton alkatrészek nagy mennyiségben és rendszeresen történỏ beszállitása, a végtermék földi közlekedési eszközzel piacra szállítása). A gyakorlatban általában csak a vonzáskörzet kifejezést használják a repülőtérrel funkcionális kapcsolatban levô területek megnevezésére, fúggetlenül attól, hogy milyen irányú az interakció.

A vonzáskörzethez képest a repülötér hátországa (hinterlandja) alatt az a terullet értendö, ahol az üzemek csak alkalmilag, nem rendszeresen veszik igénybe a repülőtér szolgáltatásait. (Amikor éppen nagy értékủ, vagy törékeny áruk, illetve pótalkatrészek gyors szállítására, vagy alkalmazottaik távolra utaztatására van szükség egy váratlan helyzet folytán.)

Ez már a vonzásterület külső övezetének, vagy akár a vonzáskörzeten túli területnek is felfogható, ahol sok vállalat veszi igénybe mérsékelt intenzitással a légi közlekedést (szinte kizárólag a nagytávolságú vonalakkal létesüló összeköttetések iránt van keresletük) anélkül, hogy számukra a repülőtérnek telephelyet alakító ereje lenne.

A repülőterek gazdasági hatásának térbeli kiterjedését befolyásoló tényezők közül a legfontosabbak:

- a repülötér környéki térség közlekedési feltártságának minősége, a repülötér közvetlen elérését lehetővé tevő fơldi közlekedési pályák (vasutak, utak) minő- 
sége és vonalvezetése, az általuk érintett telepưlések száma és a vizsgált repülótérnek a tőbbihez való térbeli viszonya a regionális léptékủ vonzáskörzetet alakítja, ezzel szemben

- az adott repúlötérről közvetlen légi járatokkal elérhetỏ városok száma, azok gazdasági súlya és

- a légi járatok száma, a forgalom intenzitása a repülőtér régión túli, nagytérségi vonzásterületét jelöli ki.

\section{A repülőterek mint a területfejlesztés új és gyakran ellentmondásos tényezõi}

Nemzetkőzi kutatási programok olyan eredménnyel jártak, hogy Európa gazdaságának mind jelentỏsebb tényezổi a repülőterek (közelebbröl a 259 ACI-tag repülötér), amelyek közvetetten 7 millió munkahelyet biztositanak, és évente mintegy 300 milliárd dollár profitot hoznak.

A gazdasági haszonnal és a légi közlekedés tömeges igénybe vételével elérhetö nagyobb mobilitással, jobb informáltsággal és a megtakarított idővel, mint a légi közlekedés abszolút pozitiv oldalóval szemben áll a zöldmozgalomnak a repülôterek korlátozására irányuló követelése. A két, egymással homlokegyenest ellenkezö felfogás közötti konszenzus alapelve a következö lehet: olyan egyensúlyi helyzetet kell elérni,

- amely a lehetö legkisebb mértékủre csökkenti a légi kőzlekedés környezetre káros valamennyi hatását, és

- amely a lehető legtöbb ember számára megteremti, ső́t a lehető legnagyobbá teszi a légi közlekedésből származó gazdasági, társadalmi, valamint környezeti elönyöket.

A repulőterek gazdaságfejlesztő képességének és ugyanakkor a hiányuk fejlödést visszafogó tulajdonságának felismerése eredményeként mind gyakrabban szerepelnek a regionális - területfejlesztési tervekben is a régi repterek rekonstrukciójára, az ellátatlan területeken új repülöterek építésére javaslatok. Ezek nem egy esetben nélkülözik a szakmai józanságot, szinte csodát várnak tölük. A repülốtereket, egyáltalán a légi közlekedést azonban nem szabad önmagában és öntörvényü területfejlesztési eszköznek tekinteni. Egy régió teljes gazdasági-társadalmi keresztmetszetének elemzésére alapozva a teljes közlekedési ágazat keresleti és kínálati oldalának mérlegszerủ ẻrtékelését elvégezve, más tényezókre is figyelemmel lehet megtalálni a repülöterek, illetve a légi közlekedés reális helyét a vizsgált térségben, mert a légi közlekedés is egyre inkább más közlekedés-hordozókkal együtt, intermodális rendszerekbe integráltan tud hatékony lenni a térségek dinamizálásában.

Összegzésképpen megállapítható, hogy a repüloôterek ma már nélkülözhetetlen telephely-tényezói mind a modern ipari, mind a posztindusztriális szolgáltatói társadalom fejlódésének.

Nemzetkőzi gazdasági kapcsolatok légi közlekedés nélkül elképzelhetetlenek. Azoknak a régióknak, amelyeknek repulōteriuk és azon keresztül légi közlekedési kapcsolatuk van, jobb a telephely minőségulk. Mindazok a fejlesztõ lépések, amelyeket a légi közlekedés fôldi (repülö- 
téri, irányítóhelyi stb.) infrastruktúrájában tesznek vagy terveznek, nemcsak a közvetlenül érintett régió jövöjére, de az egész ország mint „telephely” értéke szempontjából igen kedvező hatással vannak. A teljesítőképes légi közlekedési rendszernek szüksége van a mindenkori keresletnek megfelelő repülőtér hálózatra.

A légi közlekedés és a társadalom értéktermelõ képessége között (volumenüket tekintve) szoros az összefüggés nemcsak egy adott időpontban, de az időfolyamatban is. A két görbe az időbeli ciklikus változásokat jól indikálva nagyjából együttmozgó, kisebb fáziskésésekkel és a légi forgalom tompítottabb amplitúdóival.

A repülőterekkel való ellátottság és a repülőtéri beruházásokról hozott kormányzati döntések tétje

Mindenfajta területfejlesztési törvény ellenére jelentős különbségek adódnak a légi közlekedési ellátottságban még fejlett országokban is. A repülöterek egyenetlen megoszlása következtében gyengén ellátott területek is léteznek.

A légi közlekedési szolgáltatásokkal területeket lefedö ellátási nehézségeknek az az oka, hogy a légi közlekedés technikailag korlátozottan képes sürü hálózat alkotására, valamint „állomásai" illetve infrastruktúrája kiépitésének tökeigénye nagy. A kisebb repülöterek (mint amilyenek a regionális repülöterek és leszállóhelyek) létesítése természetesen lehetőséget nyújthat a hálózat süritésére.

A sủrủn települt országokban a repülöterekkel ellátottság javításával szemben áll a lakosság (egyes részeinek) ellenállása a repülőterek közvetlen környékének emissziós terhelése miatt.

A polgári repülőterek (nagy része) közjavak, közérdekeket szolgáló létesítmények, amelyek rendelkezésre bocsátása részben az állam, részben a területi önkormányzatok közös teherviselésével a kínálatpolitikai szempontok érvényesítésével történik.

\section{A térelméletek alkalmazásának lehetőségei}

A térelméletekben kimutatott törvényszerüségeknek elvileg meg kellene nyilvánulniuk a repülöterek tertileti elhelyezkedésében, egymáshoz való térbeli viszonyukban. Különösen akkor, ha a repülőtereket a különböző szolgáltatások kínálatának központjaként és a légi összeköttetéseket a magas vagy magasabb szintú központi helyek „termékeként” értelmezzulk (pl. a Christaller-féle központi helyek modelljének analógiájára), valamint amikor a repülöterek vonzáskörzetén belül a kifelé csökkenő intenzitást értelmezzük (pl. a Thünen elméletben megfogalmazott alapvetö összefüggések alapján). Ugyanígy van relevanciája a Böventer-féle szolgáltatási területi modellnek is a repülő́terek térbeli helyzetének megítélésében azzal a tétellel, hogy egy központi intézmény telephelyének (amilyen esetünkben a repülőtér) az általa vonzott vónzásterület súlyozott központjában kell elhelyezkednie. Tulajdonképpen az országok egész területét lefedő repülötér hálózati rendszerek igényének megfogalmazásakor a homogén teret feltételező christalleri központi hely textúra jó „szamárvezetô” lehet. Azonban e geometriai térmodellek alkalmazá- 
sában nehezen kiküszöbölhető nehézségek adódnak, mivel a területek igencsak inhomogének.

A repülôtereknek a térelméletek szerinti szabályos területi megoszlása és nagysághierarchiája csak jelentós korlátozások mellett érvényesül egyebek mellett már csak azért is, mivel a repülőtér-építési és bővítési engedélyek kiadása nem kizárólag gazdasági megfontolásokon alapszik.

Ezzel kapcsolatban itt is utalnunk kell a politikai döntéshozók (mindenekelött a lakótelepüléseken müködők) különböző, részben szubjektív és nem gazdasági meghatározottságú érdekhelyzetének további problematikájára, a zöldmozgalmak ellenakcióira, amelyek képesek befolyásolni a repterek területi megosztását.

\section{Egy példa a légikikötők terület- és városfejlesztô szerepére (Az új müncheni repülótér)}

München repülőtereit a beépitett várostest terjeszkedésével egyre távolabb kellett megépíteni. Az elsőt, az oberwiesenfeldit 1938-ban át kellett telepíteni a keleti előtérbe. Azonban ezt a „München - Riem” repülőteret is „utolérte a város”, ezért a legújabbat München központjától mintegy 30 km-re északra, Freising közelében hozták létre. A müncheni repülötér ismételt áthelyezésénél a mérlegelés tárgya kevésbé a Riem repülőtéren fennálló helyhiány volt, sokkal inkább biztonsági okok játszottak közre.

$\mathrm{Az}$ új München II. (Franz Josef Straussról elnevezett) repülőteret 1992. május 17-én nyitották meg. A befejezésig a tervek megváltoztatása, az érintett lakosság igényei és egyéb okok következtében 23 év telt el.

\section{A repülótér létesítését motiváló és regionális politikai tényezók}

$\mathrm{Az}$ utóbbi évtizedekben mind világosabbá vált, hogy a gazdaságilag oly jelentős bajor fövárosnak modern és nagy teljesitményü repülőtérre van szüksége. Frankfurt mint a legjelentősebb német légi forgalmi „fordítókorong” erős túlterheltsége miatt München új repülöterének nemcsak fontos vonzáskörzeti forgalomgyüjtő funkciót kell ellátni, hanem egyre inkább a Frankfurtot tehermentesítőt is. A modern infrastruktúrák itteni magas teljesitöképessége alapján ez a feladat még nagyobbra értékelendő, mint a többi másodlagos fordítókorong funkciójú Berlinnél, Düsseldorfnál és Hamburgnál.

$\mathrm{Az}$ óriási repülőtér építésének szükségességét részben az Európai Unió viszonylatában is kiemelkedỏ elektronikai, gépipari, gépkocsigyártási és vegyipari kapacitásnak, oktatási és kutatási intézményeknek örvendö, gyorsan fejlődő Bajorország közlekedési szükségletei, részben magának Münchennek (mint nemcsak ipari, hanem szolgálóközpontnak) a szüikségletei indokolták. (E nagyváros Németországban az első helyet foglalja el a biztositó szakmában, másodikat a pénzügyletekben.) Politikailag az EU kiszélesedése, a két Németország egyesülése, a városhoz viszonylag közeli kelet-európai országokban megnyíló új piac is motiválta az építkezés meggyorsítását. 
München II. kettơs (egyenként $4 \mathrm{~km}$ hosszú és $60 \mathrm{~m}$ széles) le- és felszálló pályái oraánként elméletileg 75 repuloógép indulását, illetve érkezését teszik lehetóvé. Ezáltal forgalmi kapacitása nagyobb, mint a frankfurti légikikőtőnek. A forgalmi épületek, létesítmények évi kapacitása 15 millió utas, amely egy újabb terminállal 30 millió utas kiszolgálását teszi lehetővé. Az SBahn végállomása a kơzponti épületben van. Itt hozták létre Európa legnagyobb autóbérlési központját és az összesen 10 ezer féróhelyes három fedett autóparkoló házat. A repulớtér teherforgalmi kapacitása 250 ezer t/év, de ez könnyen egymillió tonnára nơvelhetô.

\section{A müncheni repülôtér szerepe és helye az európai légi közlekedésben}

Mưnchen személyforgalma az új repưlötér ătadása után jelentősen megnőtt és meghaladta az évi 12 millió utasszámot. (A kapacitáskihasználás 80\% kơrülì.) A menetrend szerinti járatok száma 141000 , a nem menetrendszerủeké 34000 (ezen belül a charter-járatoké 24000 ).

Mưnchen II. igazån az Európán belủli nemzetkơzi légi forgalomban tünik ki, összesen 60 európai városba repủlnek innét a gépek, amelyek az összes nemzetközi forgalmának $86 \%$-át teszik ki.

A bajor fóvárosból gyakorlatilag Európa valamennyi régiójába, beleértve Kelet-Közép- és Kelet-Európát is naponta tơbb járattal el lehet repủini. Különơsen Dél-Európával van kiterjedt légi kôzlekedési kapcsolata. (Jellemző, hogy nemzetkózi légi járatai 14\%-ának végállomása Olaszországban és Máltán van. Ezek a Svájc felé irányuló járatokkal egyutt már tơbb mint 25\%-ot tesznek ki. A nyári szezonban még sok charter-járat is növeli ezt az arányt.) KeletKözép- és Kelet-Európa felé tíz vonalon hetente 80 járattal van 12 célrepülổtér felé összekőttetése. A keleti kapcsolatok erősődésében nagy szerepe volt a politikai kőzeledésnek, új államok keletkezésének, és ezzel kapcsolatosan új légitársaságok létrehozásának.

$\mathrm{Az}$ interkontinentális közlekedésnek az észak-amerikai viszonylat kivételével alárendelt a jelentősége: Dél-Amerikával és Ausztráliával egyáltalán nincs légi kapcsolata, Afrika és Ázsia néhány nagyvárosával is csak kevés menetrend szerinti járat köti össze. A Japánnal kialakult összekőttetés gyengesége arra vezethető vissza, hogy a japán cégek eddig fơként Düsseldorf térségében telepedtek le, hozták létre kirendeltséguket, ezért elsősorban Düsseldorf és Frankfurt repülöterét használják. A távol-keleti és délkelet-ázsiai dinamikusan fejlődő térség tơbbi országával a nagytávolságú légi kapcsolat pedig a „megarepülőtereken" (Frankfurt, London, Párizs) keresztül realizálódik.

Az USA és Kanada tơbb nagyvárosába viszont leszállás nélkül kőzlekednek innét a gépek (Atlanta, Chicago, Cincinnati, Miami, New York, Los Angeles, Toronto szerepeltek az 1993. évi menetrendben). A tőbbi kontinens repülőterei közül Tokión kívül Johannesburg, Bali, Kuala Lumpur, Dubai, Bangkok, Havanna, Medan felé nyitottak járatokat.

\section{A repülőtér jövője}

Az új légikikötő jelenleg még fejlődésének kezdetén tart. Az már egyértelmủen felismerhető, hogy Dél-Németországon belül Stuttgarttal és Nürnberggel szemben fỏlénye tovább nỏtt. Ez jól megmutatkozik regionális vonzáskörzetének kiterjedtté válásában is. Középtávon Mưnchen II. a német repülőterek közül Berlinnel és Düsseldorffal versenyezhet a második helyért. Kapacitás-tartalékai alapján a többiekhez viszonyítva jobb indulási pozícióban van. Mivel a frankfurti repủlőtér már régóta kinőtte kapacitását, a jơvőben növekedni fog a másodlagos fordítókereszt funkciót betőltő Mưnchen forgalmi jelentősége Németország légi kőzlekedésében. 
Azonban egyelöre ez a tendencia alig észlelhető a gazdasági recesszió miatt. Söt, a légi teherszállításban a várt fellendülés nemcsak hogy elmaradt, de éppen ellenkező tendenciájú, visszaesés történt az 1990-es évek első felében. A müncheni repülőtérre teherautóval szállitott „légi” teheráru nagy részét közúton szállítják tovább Frankfurt felé.

Az 1993. évi teherszállítás 57 ezer tonnás teljesítménye messze elmarad az évi 270 ezer tonnás kapacitástól. München II. pozíciójának alakulása a liberalizált európai légi közlekedésben még viszonylag nyitott, sok benne a bizonytalanság. Az egyik lényeges kérdés, hogy mennyire állja majd a versenyt az olyan, nem nagy távolságra fekvő másodlagos fordítókereszt repülőterekkel szemben, mint Zürich vagy Milánó. Döntỏ lehet, hogy a jelentős nemzetközi légitársaságok milyen mértékben vonják be Münchent a vállalati stratégiájukba. A jövöben Európában a repülőterek fejlödése szempontjából az egyes légitársaságok versenyszituációja és piaci sikere, eredményei lényeges szerepet játszanak. Az európai légitársaságoknál az átalakulás kevésbé követi az amerikai, világméretekre kialakított egyủttmüködési stratégiát a Föld legfontosabb három légi közlekedési piacán, Észak-Amerikában, Európában, Kelet-Ázsiában. München fejlödése erősen fủgg a forgalmában legnagyobb súllyal jelentkező Lufthansa vállalati eredményétöl, amely itt a kelet-ázsiai forgalmat, járatszámot lényegesen növelni akarta, azonban az általános recesszió miatt a fejlesztési elképzeléseit nem tudta megvalósítani.

A globális üzleti szövetségek mindinkább garanciák lehetnek a világméretú légi közlekedés gazdasági talpon maradásához. Európa jövő̉jének perspektíváit nem utolsó sorban a globális méretủ háromszöget alkotó fơpiacok gazdasági erőinek elérhetöségébőll lehet levezetni.

München jövőjének egyik lényeges kérdése, hogy mennyire állja majd a versenyt az olyan, nem nagy távolságra fekvő másodlagos fordítókereszt repülōterekkel szemben, mint Zürich vagy Milánó. Döntö lehet, hogy a jelentős nemzetkőzi légitársaságok milyen mértékben vonják be Münchent a vállalati stratégiájukba.

\section{A repülötér kedvezỏ hatása a helyi gazdaságra}

Annak ellenére, hogy a müncheni repülötér kapacitását még messze nem tudják kihasználni, és a tervezettöl még elmarad a teherforgalom mértéke, mégis szinte önálló gazdasági szektort képez már a repülőtér megnyitásáig ide települt mintegy háromszáz cég és intézmény közel 12 ezer alkalmazottal. A város tágabb környékén további 30 ezer munkahely létrejöttével számolnak, amelyek közvetlenül összefüggnek a repưlötérrel. A légikikötő a tágabb régiójában növekedési impulzusokat vált ki, fejlesztỗ hatása még a tóvoli Alsó-Bajorországra és Felsö-Pfalzra is kisugårzik.

Különős jelentõsége van a turizmus élénkítésében, mivel Németország valamennyi tartománya közul Bajorországnak van a legtöbb külfôldi látogatója. Az új légikikőtő nagyregionális vonzáskörzetébe tartozó Bajorországból, Dél-Németországbobl, Svájcbobl, Ausztriából és Észak-Olaszországból évente 15 millió, Németország és Európa távolabbi régióiból, valamint a tengerentúlról évente átlagosan 20 millió látogató érkezik Münchenbe. Ennek az embertömegnek jelentékeny része potenciálisan a légikikötõ utasállományát képezheti. 


\section{A regionális repülőterek hatás a a gazdasági-regionális fejlödésre}

A regionális repülöterek létrejöttük, eredetük szerint két csoportba oszthatók:

- A teljesen új, ,zöldmezös beruházásként”, többnyire területfejlesztési projektek keretében épültek. Ilyenek a portugáliai Visen (állami támogatással), vagy például a kis ír regionális repterek Sligoban és Waterfordban.

- A második csoportot a régebb óta meglevő, de más célra használt repterekbōl átalakitottak alkotják, mint pl. azok, melyek a volt NDK területén, de más országokban is az egykori hadi repülőterek konverziójával jöttek létre.

A regionális repülőterek gazdaság- és területfejlesztő hatásai több tényező (foglalkoztatási, közlekedési elérhetöségi stb.) megnyilvánulásában, hatásmechanizmusában természetesen hasonlóak a nagy repülőterekkel kapcsolatban már ismertetettekhez, csak kisebb méreteket öltenek.

- A költségelőnyök mennyiségileg az utazási idő tört részére csökkenése általi nyereségben jelennek meg. Azaz a közúti és vasúti kőzlekedéssel szembeni kisebb utazási idő ráfordításban.

- Az idômegtakaritással szemben (ami természetesen pénzben is kifejezhető) a tényleges haszon kimutatása már komplikáltabb. Nyilvánvaló, hogy a legáltalánosabb megközelítésben a dinamikusabbá és sokirányúvá váló személy- és áruszállításból következik áttételesen az anyagi haszon jó része.

- Az elöbbivel szemben a repülóterek által létrehozott szolgáltatások konkrét hasznát közvetlenül mérni lehet.

- Primer hatások:

- a repülőtéren (a különböző szolgáltatásokban) foglalkoztatottak értéktermelő munkája és a vásárlóerőt növelö keresete a repterek fejlesztésével növekvő tendenciájú (pl. a Basel-Mulhouse repülötér szolgálatában álló dolgozók száma 1750-ről 2300ra nőtt az 1986-1988 közötti bỏvítések, a járatszámok növekedése eredményeként, Maastricht repülőtéren az 1980-as években 325-rỏl 670-re változott a foglalkoztatottak száma);

- közvetett hatásként a repülőtér környékén is bekövetkezik bizonyos szolgáltatások (vendéglátóipar, szálloda, autókölcsönzö, taxi, autóbusz, vasútállomás, parkolás) kialakulása.

- Másodlagos hatások adódnak:

- a repủlőterek és a légitársaságok által eszközölt árubeszerzésekből,

- a repúlőtereken és a velük funkcionális kapcsolatban lévő környékükön foglalkoztatottak jövedelmeiböl,

- a repülő́terek által indukált turizmus bővítéséből és az üzleti utazások számának növekedéséböl, amelyeknek fejlesztő hatása van az idegenforgalmi infrastruktúrára is, erösíti a helyi gazdaságot,

- a repülőterekkel (terminálokkal, futópályákkal stb.) kapcsolatos beruházásokból, építkezésekből, berendezési és szerelési munkákból.

A hatások nagyságában mutatkozó természetes különbségek mellett azonban érzékelhetők a nagy repülöterektől megkủlönböztető sajátságos vonásai is:

- A regionális repülöterek gyakran a nem, vagy csak igen körülményesen és drágán fejleszthető nagy légikikötőket tehermentesítỏ létesítmények, tehát egyfajta alternatívát képeznek egy térség légi közlekedésének fejlesztéséhez. London kapacitás túltelítettségéből húznak hasznot Délkelet-Anglia kis repülőterei, de bizonyos mértékig hasonló megfontolásból fejlesztették fel a dániai Billundot is, 
amely elsősorban a teherszállításban helyettesíti Koppenhágát, ahogyan Maastricht egyre inkább Amszterdam tehermentesítōje az áruszállításban.

- A regionális repülőterek általában követik a gazdasági fejlödést, azaz a gazdaság fejlődése hívja életre öket.

- Ugyanakkor a kis regionális repülőtereknek viszonylagosan nagyobb regionális fejlesztó szerepük van, mint a nagyoknak, szervesebben beépülnek a térségek gazdaságába.

A regionális repülöterek is képesek vonzani a befektetéseket, elösegítik a fejlesztéseket a régióban, általuk sok esetben önállósulni képesek azok a részlegek, amelyeket távoli vállalati központokból irányítottak.

Jó néhány példa bizonyitja, hogy a repülötér-fejlesztés milyen hatással van a hazai, sőt mindinkább a külfôldi tổke vonzására. Irrországban a külfôldi töke befektetések $80 \%$-ára a repülötér közelsége volt hatással. Dániában, Esbjergben és környékén a társaságalapitások 63\%-a a repülőtér közelségére alapozott. Walesben és Skóciában abban, hogy az iparban foglalkoztatottak $40 \%$-a külföldi cégeknél dolgozik, ugyancsak nagy szerepe volt a regionális repülötereknek.

A regionális repullőterek sikerei nagymértékben függnek a repülötér természetes vonzásterületének méretétöl, gazdasági fejlettségétől és üzleti életének élénkségétől.

Hogy az adott regionális repülötér milyen mértékben képes pozitiv hatást gyakorolni az üzemek telephelyválasztására, nagymértékben a régió térségi és különösen közlekedési helyzetétól függ, azaz attól, hogy a repülötér periférikus területen, vagy egy rossz földi közlekedési kapcsolatú régióban, esetleg egy ipari agglomerációban van-e.

A periférikus régiók repülöterei kevésbé szolgálnak telephelytényezőként az új ipari üzemek általános okokra visszavezethető megtelepedésekor, hanem sokkal inkább a már meglevő olyan ïzemek számára fontosak, amelyek az export- vagy importorientációjuk következtében légi összeköttetésekre utaltak (pl. ilyen helyzetben volt a német ưjraegyesítés elötti idökben Bayreuth és Hof városok repülōtere). A svájci határhoz közeli, Bodeni-tó melletti Friedrichshafen térségében végzett vizsgálatok viszont kimutatták a reptér általi nagyobb telephelyelónyt az újonnan települt gazdasági vállalatok számára is. E térség paradoxona egyfelől a rossz szárazföldi kapcsolat (nincs autópályăja), másfelöl a kedvezỏ gazdaságstruktúra, ami abban is megnyilatkozik, hogy a további exportorientációhoz virágzó repülögépipari koncentrációval is rendelkezik.

Az eddigi tapasztalatok alapján a kővetkezö összefüggések illetve feltételek mutatkoznak meg a regionális repülöterek és a gazdasági kőrnyezetuk között:

- A regionális repülöterek számára döntö a magas szintú politikai és közösségi támogatás. Sok sikeres regionális repülötér képes vonzó hatást gyakorolni a helyi gazdasági, politikai erők támogatásra; ezzel életképes lesz. A repülötéri társaságoknak kereskedelmi alapon kell müködniük.

- A nagyon kicsiny regionális repulőterek a professzionális menedzsment nélkül általában fejlődésképtelenek.

- A fö üzleti tevékenység egyre inkább a menetrendszerü közlekedés kell, hogy legyen. A charterközlekedés, a teheráru szállítás, a repülésoktatás fontos, de csak kiegészítő tevékenység, ezekre kevésbé érdemes alapozni e reptértípus üzletét. Különleges helyzetekben azonban a teheráru forgalom is alapját képezheti 
egyes regionális repterek gazdasági eredményeinek (ahogy azt pl. Maastricht, Ostende bizonyitotta).

- A regionális repülöterek virágzása nagymértékben fưgg attól, hogy megfelelő repülőgép típusok alkalmazásával alakítják-e ki az odavezető vonalakat. Az utasok összetételétől (igényességétől), a repterek közötti távolságtól (ezzel az átlagos repülési magasságtól) és az utasok számától fủggően hol sugárhajtómüves, hol meg turbólégesavaros gépekkel kell a járatokat müködtetni, akár alternatív repülöterek beiktatásával is. (Ahol lehet, törekedni kell a nagyobb biztonság és kényelem érdekében sugárhajtómüves gépek alkalmazására, amelyekkel a rövidebb utazási idó miatt élénkíteni lehet az egy napon belüli utazásokat.)

A regionális repülőterek müködtetésének sikere nem utolsó sorban attól függ, hogy mennyire képesek vonzóvá tenni magukat a jól müködő légitársaságok számára (pl. a dél-franciaországi Montpellier repúlőtere azóta ér el jó gazdasági eredményeket, amióta a prosperáló Air Littoral társaság bázisává vált).

Nemzetközi gazdasági kapcsolatok légi közlekedés nélkül elképzelhetetlenek. Azoknak a régióknak, amelyeknek repülóterük és azon keresztül légi közlekedési kapcsolatuk van, jobb a telephely minöségük. Mindazok a fejlesztő lépések, amelyeket a légi közlekedés fơldi (repuloótéri, irányítóhelyi stb.) infrastruktúrájában tesznek vagy terveznek, nemcsak a közvetlenül érintett régió jövöjére, de az egész ország, mint "telephely” értéke szempontjából igen kedvezó hatással vannak. A teljesítőképes légi közlekedési rendszernek szüksége van a mindenkori keresletnek megfelelö repülötér hálózatra.

\section{Irodalom}

CAA: London Area Airports Survey 1993. (1993) London, Civil Aviation Authority.

D'Connor, W. (1989) An Introduction to Airline Economics. New York, Praeger.

De Murias, R. (1989) The Economic Regulation of International Air Transport. Jefferson (USA), Mc Farland.

Diegruber, J. (1991) Erfolgsfaktoren nationaler europäischer Linienfluggesellschafien im Markt der 90-er Jahre. Munchen, Konstanz.

Frischkorn, G. (1980) Der Wettbewerb zwischen der Deutschen Bundesbahn und den Luftverkehrsgesellschaften im innerdeutschen Personenverkehr unter Berucksichtigung verkehrsgeographischer Aspekte. - Frankfurter Wirtschafts- und sozialgeographische Schriften. 32.

Haas, H.-D. (1994) Europaischer Luftverkehr, und der neue Flughafen Munchens. - Geogr. Rundschau. 5. 247-281. o.

Hilsinger, H.-H. (1976) Das Flughafen - Umland. Eine wirtschaftsgeographische Untersuchung an ausgewählten Beispielen im westlichen Europa. - Bochumer Geographische Arbeiten. 23.

Maller, H. (1992) Die Flughafen-S-Bahn Munchen. - Die Bundesbahn. 3. 291-304, o.

Nigel, D. (1994) Airline hub operations in Europe. - Journal of Transport Geography. 4. 219-233. o.

Pagina, A. (1992) Die Bedeutung von Verkehrsflughafen für Unternehmungen. Eine exemplarische Untersuchung der Flughafen Dusseldorf und Koln/Bonn fur Nordrhein-Westfalen. - Europäische Hochschulschriften. 5.

Pompl, W. (1991) Luftverkehr, eine ökonomische Einführung. Berlin, Springer V.

Reinhardt, U. (1993) Die Stellung des Ferienflugverkehrs im europaischen Luftverkehr. - Journal des Lufiverkehrs. 3. 238-248. o.

Riemer, P. (1959) Verkehrsflughafen und deren Beziehungen zur Stadt. Dusseldorf, Ratingen.

Shearman, P.(1992) Air Transport - Strategic Issues in Planning and Development. London, Pitman.

Willeke, R.(1968) Wirtschaftliche Gestaltungstendenzen des modernen Luftverkehrs. Köln-Madrid, Ed. Civitas. 


\section{AIR TRANSPORTATION AND SPATIAL DEVELOPMENT}

\section{FERENC ERDŐSI}

Rail transportation and inland water transportation - among all sectors of transportation - have influenced and differentiated the most obviously the spatial development and the development of settlements in Hungary due to the geographical conditions and historical evolution. Until the end of the 1990s the effect of transportation wasn't appeared clearly. It has been manifested rather along motorways and near to bigger cities but mostly within the scale of small regions. The Hungarian air transportation having only one centre is corresponding to the mono-centric transport network of the country. Consequently, the regional effect of it could be hardly examined for the time being. Although in the recent years the whole country likes to establish and develop regional airports, only some of them have the substantial base. Information is available for national researchers of spatial sciences about the interaction between air transportation and settlement and regional development is rather restricted. The study likes to contribute in some way to the enlargement of the related knowledge. 